\title{
Comparison of direct and geodetic mass balances on a multi-annual time scale
}

\author{
A. Fischer \\ Institute of Meteorology and Geophysics, University of Innsbruck, Austria \\ Received: 28 June 2010 - Published in The Cryosphere Discuss.: 23 July 2010 \\ Revised: 11 February 2011 - Accepted: 16 February 2011 - Published: 24 February 2011
}

\begin{abstract}
The geodetic mass balances of six Austrian glaciers over 19 periods between 1953 and 2006 are compared to the direct mass balances over the same periods. For two glaciers, Hintereisferner and Kesselwandferner, case studies showing possible reasons for discrepancies between the geodetic and the direct mass balance are presented. The mean annual geodetic mass balance for all periods is $-0.5 \mathrm{~m}$ w.e. $\mathrm{a}^{-1}$, the mean annual direct mass balance $-0.4 \mathrm{mw}$.e. $\mathrm{a}^{-1}$. The mean cumulative difference is $-0.6 \mathrm{~m}$ w.e., the minimum $-7.3 \mathrm{~m}$ w.e., and the maximum $5.6 \mathrm{~m}$ w.e. The accuracy of geodetic mass balance may depend on the accuracy of the DEMs, which ranges from $2 \mathrm{~m}$ w.e. for photogrammetric data to $0.02 \mathrm{~m}$ w.e. for airborne laser scanning (LiDAR) data. Basal melt, seasonal snow cover, and density changes of the surface layer also contribute up to $0.7 \mathrm{~m}$ w.e. to the difference between the two methods over the investigated period of $10 \mathrm{yr}$. On Hintereisferner, the fraction of area covered by snow or firn has been changing within 1953-2006. The accumulation area is not identical with the firn area, and both are not coincident with areas of volume gain. Longer periods between the acquisition of the DEMs do not necessarily result in a higher accuracy of the geodetic mass balance. Trends in the difference between the direct and the geodetic data vary from glacier to glacier and can differ systematically for specific glaciers under specific types of climate forcing. Ultimately, geodetic and direct mass balance data are complementary, and great care must be taken when attempting to combine them.
\end{abstract}

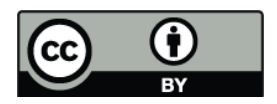

Correspondence to: A. Fischer (andrea.fischer@uibk.ac.at)

\section{Introduction}

Glacier mass balance is a sensitive indicator of climate change. Changes in glacier mass result from ablation and accumulation and are directly related to prevailing atmospheric conditions. Since glacier mass balance also governs glacier runoff, it is a valuable parameter for glaciological modeling with various climatological and hydrological applications. Over the last few years, a major effort was undertaken to estimate the global mass balance of mountain glaciers and their contribution to sea level rise (Kaser et al., 2006; Lemke et al., 2007). The mass balance could be determined by applying the direct glaciological or the geodetic method (Hoinkes, 1970). To reach a general estimate of the past and current reactions of the cryosphere to climate change, both methods are necessary. The direct method can lead to better understanding of glacier melt, while the ease of taking the measurements necessary for the geodetic method enables truly global studies. In order to use the two methods in concert, it must first be ensured that they produce comparable results. The direct and geodetic mass balance measurements both involve specific assumptions and uncertainties. To quantify these uncertainties, a number of studies compared the results of the direct mass balance to data derived from the geodetic method. Detailed investigations on Hintereisferner from 1953 to 1964 (Lang and Patzelt, 1971) and later, from 1953 to 1991 (Kuhn et al., 1999), showed good agreement between the geodetic and direct methods. Studies on Gulkana glacier (Cox and March, 2004) and Storglaciären (Zemp et al., 2010; Koblet et al., 2010) also suggested that the two methods corresponded well. In contrast, Geist and Stötter (2007) showed larger differences between geodetic and direct data collected on Hintereisferner from 2001 to 2005. On the South Cascade glacier, Krimmel (1999) found evidence of a systematic deviation between the two methods. Hagg et al. (2004) compared the direct and geodetic mass balance for the Central

Published by Copernicus Publications on behalf of the European Geosciences Union. 
Tuyuksu glacier and found that the difference of $-4.2 \mathrm{~m}$ w.e. within $40 \mathrm{yr}$ can be explained with deficiencies of the direct measurements. For specific glaciers in Tien Shan, he found deviations of up to $100 \%$ between the direct and the geodetic measurements for a $40 \mathrm{yr}$ period.

Several authors have combined direct and geodetic data to produce an optimal mass balance for specific glaciers. It is thought that the calibration of the direct mass balance with the geodetic mass balance reduces the systematic, but not the random error. Huss et al. (2009) combined direct and geodetic data into homogenized mass balance time series of Griesgletscher and Silvrettgletscher in Switzerland. Thibert and Vincent (2009) calculated a combined mass balance for the Glacier de Sarennes, because the geodetic method seems less affected by systematic errors.

Today, mass balances of only a small percentage of the world's glaciers are known. Cogley (2009) analysed 344 direct and 327 geodetic mass balance measurements. In total, $1052 \mathrm{yr}$ of mass balance data collected at 59 glaciers have been analyzed by the two methods. About as many glaciers have been observed by the direct as by the geodetic method, but the geodetic data spans four times as many balance years as the direct data. Cogley's statistical analysis showed no evidence of a systematic deviation between geodetic and direct data, but the deviations between the two methods reach more than $1.0 \mathrm{~m}$ w.e. for observed values of $+0.5 \mathrm{~m}$ w.e. to $-2.5 \mathrm{~m}$ w.e.

The results cited above suggest one question crucial to future glacier mass balance research: do data collected and analyzed for the same glacier and the same period by the direct method and the geodetic method differ systematically? If so, do seasonal snow cover, the accuracy of the DEMs, the density assumption or processes as basal melt play key roles? Does the difference between the two methods depend on variables such as the time scale of the study or the sign or magnitude of the mass balance?

The purpose of this study is to investigate and if possible begin to answer these questions by investigating direct and geodetic data from six Austrian alpine glaciers, two of them studied in great detail, over various multi-annual time scales. Examples are shown to give the order of magnitude of processes like firn cover reduction or basal melt. To investigate if the errors in the Austrian data are smaller than, similar to, or larger than errors in data from elsewhere, the results are compared to published data from six glaciers in the Alps, Northern Europe, the United States and Bolivia.

The investigations in Austria include the mass balances of Hintereisferner (HEF), Kesselwandferner (KWF) and Vernagtferner (VF) in the Ötztal Alps, Jamtalferner (JAM) in Silvretta, Übergossene Alm on Hochkönig (HK) in the Salzburg Limestone Alps, and Stubacher Sonnblickkees (SSK) in Hohe Tauern. For KWF, the DEMs are checked by a comparison to field data, at HEF, the changing firn and snow cover is shown. The Austrian data are compared to published data of Griesgletscher (GG, Funk et al., 1997), Gulkana Glacier
(GU, Cox and March, 2004), Lemon Creek glacier (LC, Miller and Pelto, 1999), South Cascade glacier (SC, Krimmel, 1999), Storbreen (SB, Andreassen, 1999), Storglaciären (SG, Zemp et al., 2010), and Zongo glacier (ZG, Soruco et al., 2009).

\section{Methods}

Glacier mass balance measurements began at the end of the 19th century (Hess, 1904). The concepts and techniques were further developed in the first half of the 20th century (Ahlmann, 1948; Finsterwalder, 1953). During this period, the geodetic method was often used as a simple way to estimate volume changes of glaciers over multi-annual time scales as an independent control (Hoinkes, 1970). In fact, using the geodetic method in this way was complicated by two reasons. First, in many cases the accuracy of photogrammetric maps of the firn area was low due to the lack of contrast on white surfaces in the stereo photos. Second, the density of the surface layer was known only rarely at that time (Hoinkes, 1970).

\subsection{Geodetic method}

The geodetic mass balance is calculated from the volume change derived from topographic data. This alone is not sufficient since estimates of the densities of the lost or gained volumes are also necessary. Two digital elevation models (DEMs) are acquired at different dates $t_{1}$ and $t_{2}$, usually at the end of the ablation period. The length of the experimental time period $\Delta t=t_{2}-t_{1}$ can vary from as little as one year to many decades. The volume change $\Delta V$ in the period $\Delta t$ is then calculated for the entire glacier either from the contour lines of elevation as described by Lang and Patzelt (1971) or with a raster method as performed by Funk et al. (1997). The multiplication of the volume change $\Delta V$ with the mean density $\rho$ results in the mass balance $B_{\text {geo }}$ within this period.

$B_{\text {geo }}=\Delta V \cdot \rho$

In most studies, the density $\rho$ is estimated, not measured. The density of the surface layer of a glacier varies with time and space and ranges between $100 \mathrm{~kg} \mathrm{~m}^{-3}$ and $917 \mathrm{~kg} \mathrm{~m}^{-3}$. Most assumed mean densities fall between $800 \mathrm{~kg} \mathrm{~m}^{-3}$ and $900 \mathrm{~kg} \mathrm{~m}^{-3}$. The mean density of $\Delta V$ changes with a sign opposite that of the mass balance, as mass gained by accumulation has a lower density than ice lost by ablation. In this study, a density of $850 \mathrm{~kg} \mathrm{~m}^{-3}$ was assumed to account for long term volume loss in the accumulation area, where the mean density is lower than at the glacier tongue.

By definition, the specific mass balance $b$ is the mass balance $B$ divided by the glacier area $A$. If the time period between the acquisition of the DEMs is more than a few years, the glacier area typically changes. In this study, the specific geodetic mass balance $b_{\text {geo }}$ is calculated by dividing the mass 


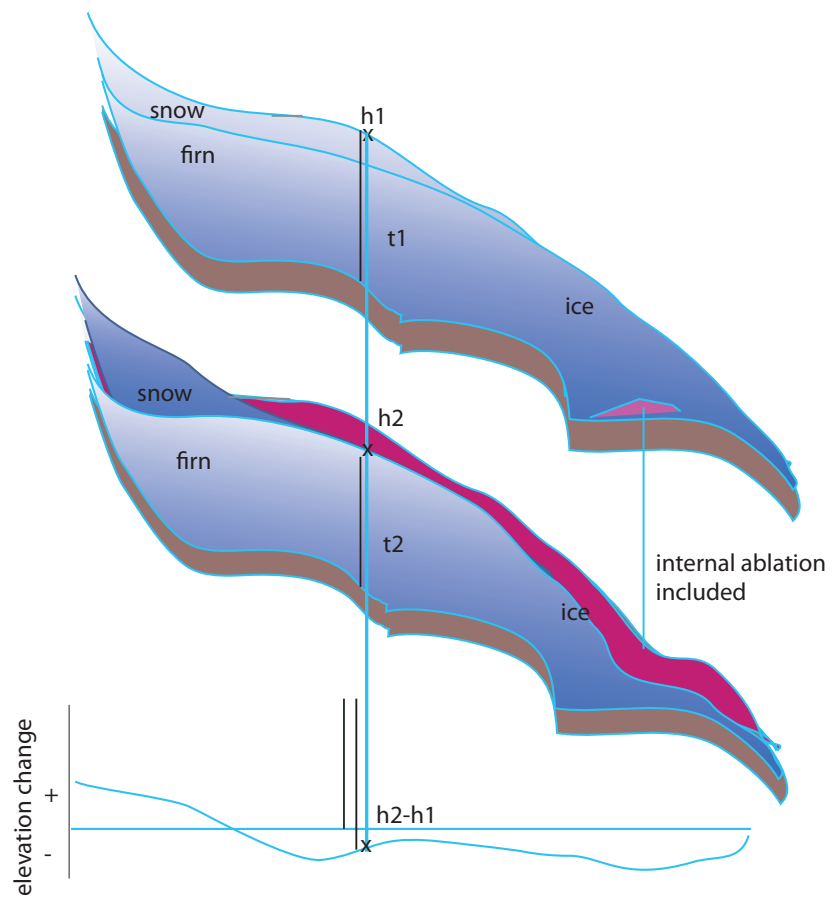

Fig. 1. Calculation of geodetic mass balance between $t_{1}$ and $t_{2}$. The mass loss at the surface removes a layer of ice, firn and possibly snow, the gained mass has a much lower density. For this surface layer subject to mass change, a mean density is assumed to convert the volume change to mass change.

balance by the larger glacier area $A$, which in case of glacial recession is $A$ at the time $t_{1}$.

$B_{\text {geo }}=b_{\text {geo }} \cdot A_{t_{1}}$

In several other studies, the initial glacier area $A_{t_{1}}$ is replaced by the average glacier area $\left(A_{t_{1}}+A_{t_{2}}\right) / 2$.

The sketch of the geodetic method in Fig. 1 shows a cross section of one glacier at the dates $t_{1}$ and $t_{2}$. The glacier is composed of ice, firn, and snow; materials with different densities are indicated by the color gradient from white (low density) to blue (high density). The glacier surface layer in this example consists of snow in the high elevations and ice below. The elevation change $h_{2}-h_{1}$ between the acquisition dates of the DEMs is calculated on a regular grid. The elevation changes are related to the surplus of snow accumulation in the upper part of the glacier and internal as well as surface ablation in the lower parts of the glacier. The density of the snow layer usually changes between $t_{1}$ and $t_{2}$. The sketch is simplified, and does not show that ice flow transports mass from the upper parts of the glacier towards the tongue. Thus for the specific grid points, the elevation change is always the algebraic sum of mass balance and ice flow. For the total glacier area, a common assumption is that ice flow does not alter the total mass of a glacier, and therefore changes of the glacier volume are related to mass changes only. In
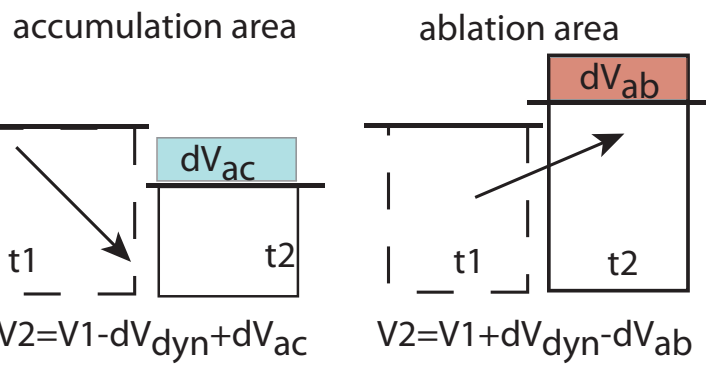

Fig. 2. The volume change $d V=V 1-V 2$ at one location between two dates $t_{1}$ and $t_{2}$ is the result of ice flow $d V_{\text {dyn }}$ and mass balance. The downward motion in the accumulation area can result in a subsidence, although accumulation $d V_{\text {ac }}$ takes place. In the ablation area, the surface can lift although ablation takes place $d V_{\mathrm{ab}}$. Without knowledge of the ice dynamics or the direct mass balance, it is not possible to separate these components.

reality, the surface altitude changes as a result of ice dynamics and mass balance (Finsterwalder, 1907; Paterson, 1994). Whereas these contributions can be separated by field measurements, the melt or accumulation at one specific location is not evident from the volume change (Fig. 2). Even when the mass balance is zero in the upper parts of the glacier, the surface can show subsidence because the ice flowing downwards removes a volume with the density of ice.

\subsection{Glaciological method}

The direct or glaciological method to measure mass balance is based on in situ determination of accumulation and ablation for the mass balance year (Hoinkes, 1970; Braithwaite, 2002). For all Austrian test glaciers analyzed in this study, the mass balance is determined within the hydrological year from 1 October and 30 September (a fixed date system). The adjustment from the floating date measurements to the fixed date system is done with the mass balance observations (Fischer and Markl, 2008). Ablation stakes are drilled in the ice and read at the end of the hydrological year. The seasonal snow cover in the ablation area on 30 September is included in the balance as mass gain. The amount of accumulation is determined by digging several snow pits and measuring the thickness and the density of the snow cover gained since 1 October of the previous year. To do so, a clear seasonal horizon must be observable in the snow cover each year. The spatial distribution of the accumulation is mapped by snow probing, if the seasonal horizon is hard enough, or by assuming a typical spatial pattern of snow patches which is found by multi-annual observation of melt patterns.

Interpolation from the measured data is performed manually by constructing contour lines of equal mass balance, in most cases including additional observations or information such as avalanches or ice exposure time. The direct or glaciological mass balance is a surface mass balance, as it does not include mass change below the surface, that is, intra- or 
Table 1. Austrian glaciers chosen for the comparison the direct and the geodetic method. abb - abbreviation, lon - longitide, lat - latitude, $A$ - area, $h_{\max }$ maximum elevation in $1969 h_{\min }$ minimum elevation 1969, last mb - last year of mass balance if not ongoing.

\begin{tabular}{llcccccc}
\hline name & abb & $\begin{array}{c}\text { lat } \\
\mathrm{N}\end{array}$ & $\begin{array}{c}\text { lon } \\
\mathrm{E}\end{array}$ & $\begin{array}{c}A \\
\mathrm{~km}^{2}\end{array}$ & $\begin{array}{c}h_{\max } \\
\mathrm{ma.s.1}\end{array}$ & $\begin{array}{c}h_{\text {min }} \\
\mathrm{m} \text { a.s.l. }\end{array}$ & $\begin{array}{c}\text { last mb } \\
\text { year }\end{array}$ \\
\hline Hintereisferner & $\mathrm{HEF}$ & $46^{\circ} 47.8^{\prime}$ & $10^{\circ} 46.2^{\prime}$ & 9.502 & 3710 & 2390 & \\
Jamtalferner & $\mathrm{JAM}$ & $46^{\circ} 51.7^{\prime}$ & $10^{\circ} 09.7^{\prime}$ & 4.131 & 3160 & 2408 & \\
Kesselwandferner & $\mathrm{KWF}$ & $46^{\circ} 50.3^{\prime}$ & $10^{\circ} 47.9^{\prime}$ & 4.241 & 3490 & 2720 & \\
Stubacher Sonnblickkees & $\mathrm{SSK}$ & $47^{\circ} 07.9^{\prime}$ & $12^{\circ} 36.0^{\prime}$ & 1.772 & 3030 & 2500 & \\
Übergossene Alm & $\mathrm{HK}$ & $47^{\circ} 25.6^{\prime}$ & $13^{\circ} 03.7^{\prime}$ & 1.636 & 2845 & 2630 & 1996 \\
Vernagtferner & $\mathrm{VF}$ & $46^{\circ} 52.6^{\prime}$ & $10^{\circ} 49.0^{\prime}$ & 9.563 & 3628 & 2717 & \\
\hline
\end{tabular}

subglacial melt or accumulation. The direct mass balance is defined in the vertical direction, so that it is calculated for the glacier area projected on a map and not the real surface area, a topic which was controversially discussed by Meier (1962), Jacobsen and Theakstone (1995, 1996), Kaser (1996), and Rabus et al. (1996). The effect on Hintereisferner is small, since the steep areas are located in higher parts of the glacier and show small mass changes (Fischer et al., 2011).

\subsection{Investigations of the accuracy of the mass balance measurements}

Several studies analyze the accuracies of the different methods to determine the mass balance. Some of these studies compare direct and geodetic data, others direct data only. Most studies analyze the data statistically, distinguishing systematic and stochastic errors; others are based on case studies. These concepts of stochastic and systematic errors are based on repeat experiments under the same conditions, creating a large data set where one result does not influence the other. This concept is rarely applicable to geodata, because the processing creates a interdependency of all data points on fixed external factors, for example, the coordinates of the ground control points. Another problem is the small sample size of certain datasets, for example, stake data or DEMs, which introduces an uncertainty in distinguishing between the variability of the signal and the noise, that is, in the basic stochastic model. For example, as a result of surface albedo changes or supraglacial rivers, the mass balance measured at one stake can significantly deviate from neighboring stakes in one year. This is not the result of errors, but the correlation to the other stakes is lower, as shown by Kuhn et al. (1999) for stakes at Hintereisferner. Nevertheless, all results provide valuable indicators of our confidence in different kinds of mass balance data, although it is still an open question if all glaciers follow the same statistical model and show the same error characteristics. For example, on some glaciers the stakes are redrilled annually, on others not. An erroneous stake reading will propagate in the first case, but compensate in the latter. The accuracy of the direct mass balance depends on the number of stakes and pits. For South Cascade glacier,
Fountain and Vecchia (1999) found annual root mean square errors of up to $\pm 0.33 \mathrm{~m}$ w.e. by analyzing the variability of the mass balance from a quadratical model. Jansson (1999) found an uncertainty of $\pm 0.1 \mathrm{~m}$ w.e. $\mathrm{a}^{-1}$ for Storglaciären. Analyzing the mass balance of this glacier, Zemp et al. (2010) used a stochastic uncertainty of $\pm 0.1 \mathrm{~m}$ w.e. $\mathrm{a}^{-1}$ for the years after 1965 and doubled the uncertainty for the years before. Thibert and Vincent (2009) analyzed $51 \mathrm{yr}$ of mass balance for Sarenne glacier and stated that systematic errors in the the mass balance increase linearly with the number of years, and stochastic errors increase with the square root of the period length. They assume that the errors are uncorrelated and found an annual error of the direct mass balance of typically $0.2 \mathrm{~m}$ w.e. $\mathrm{a}^{-1}$, corresponding to a relative error of $3.2 \%$ (1.04 mw.e.) for 1952-2003. From Eqs. (1) and (2), it follows that the accuracy of the geodetic mass balance depends on the accuracy of the DEMs, the density assumption, and the area measurements. Several studies investigated all these components and the total errors with geostatistical approaches. For Svartisen ice cap, Rolstad et al. (2009) analyzed the geodetic mass balance and found an accuracy of $\pm 0.9 \mathrm{~m}$ w.e. to $2.2 \mathrm{~m}$ w.e. Zemp et al. (2010) and Koblet et al. (2010) performed a very detailed analysis of the errors of the volumetric mass balances for Storglaciären. They considered photogrammetric errors, density assumptions, survey dates, area uncertainties, internal mass balance, superimposed ice, and flux divergence and found errors of between +0.02 to -0.07 m w.e. $\mathrm{a}^{-1}$.

\section{Test sites and data}

Six Austrian glaciers were selected as test sites for the comparison of direct and geodetic mass balance data (Table 1, Figs. 3 and 4): HEF, VF and KWF in Ötztal Alps, JAM in Silvretta, SSK in Hohe Tauern, and HK in the Salzburg Northern Limestone Alps. For all these glaciers, long term direct and geodetic data are available. For 1969 and 1997 to 2002, surface elevation data are available from the first and second glacier inventories (Patzelt, 1978; Lambrecht and Kuhn, 2007; Gross, 1987). For HEF, KWF, VF and JAM the third Austrian glacier inventory (Abermann et al., 2009) also 


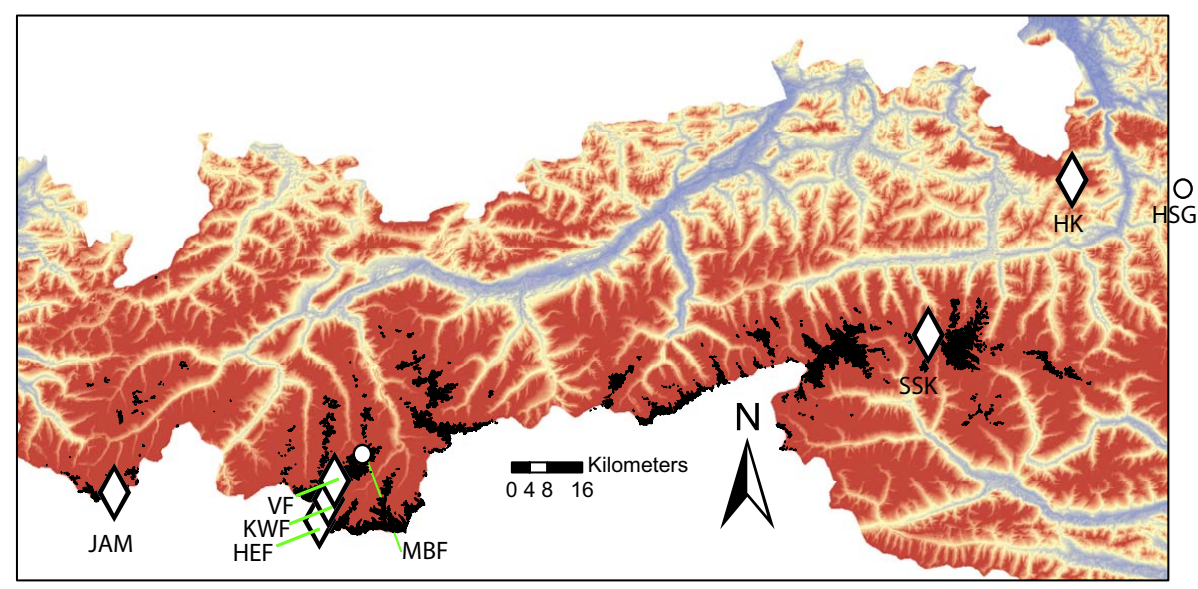

Fig. 3. Location of the Austrian test glaciers JAM,HEF, KWF, VF, SSK and HK (rhombs) and Mittelbergferner/MBF and Hallstätter Glacier/HSG (dots). DEM data from Jarvis et al. (2008).
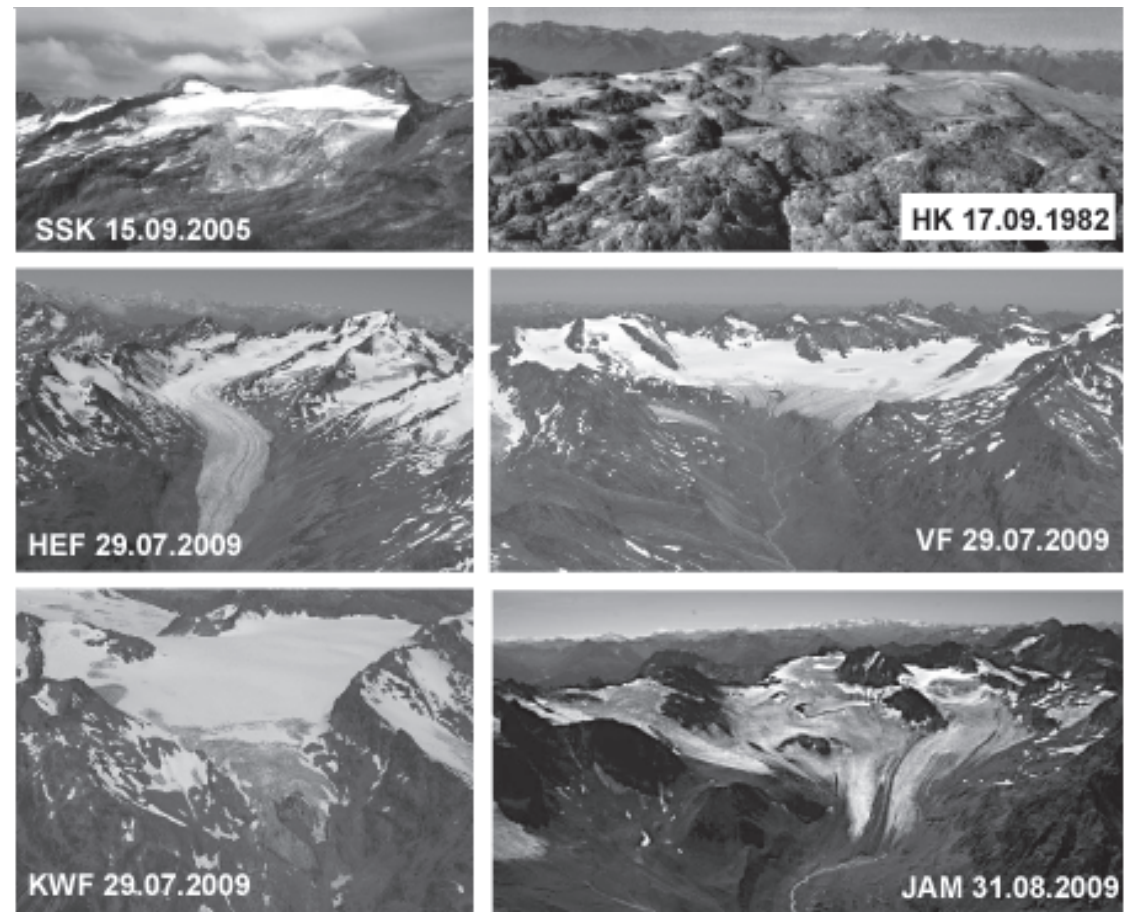

Fig. 4. Oblique photographs of the plateau glaciers SSK and HK, and the valley glaciers HEF, VF, KWF and JAM.

provides DEMs between 2004 and 2006. For HEF, four more DEMs were acquired in 1953, 1964, 1967 and 1979 (Kuhn, 1979). One DEM was acquired on KWF in 1971. All available DEMs are summarized in Table 2.

Hintereisferner (HEF) in the Ötztal Alps is the largest test glacier with an area of with $9.5 \mathrm{~km}^{2}$ and has a maximum elevation of $3710 \mathrm{~m}$ a.s.l. (Fig. 5). The valley glacier has a pronounced tongue and therefore a large ablation area with bare ice. HEF has the most negative mass balance of the test glaciers. Since the beginning of the mass balance measurements in 1952/53 the extent and the thickness of the firn cover dropped significantly (Lang and Patzelt, 1971; Fischer and Markl, 2008). Since 1952/53, many different methods of evaluating the annual mass balances have been used, so it was necessary to homogenize all of the data into a single set (Fischer, 2010). The coordinate system used for DEMs on Hintereisferner changed between 1967 and 1969 from a local Gauss Krüger system to the Austrian Gauss Krüger System. The horizontal deviation between these coordinates is up to $4 \mathrm{~m}$. At the moment, as accurate transformation parameters are not available, this might have an effect on the geodetic mass balance between 1967 and 1969 . 
Table 2. Date and method of DEM acquisition at the test glaciers JAM, HEF, KWF, VF, SSK and HK. AL - airborne laser scanning, AP airborne photogrammetry, TP - terrestrial photogrammetry. When months are given, the accurate date is not known, when two dates are given, the data is combined from two flights.

\begin{tabular}{lccccccc}
\hline Glacier & AL & AP & AP & AP & TP & TP & TP \\
\hline HEF & 23 Aug/9 Sep 2006 & 12 Sep 1997 & 14/30 Aug 1979 & Aug/Sep 1969 & Sep 1967 & 20 Sep 1964 & 4 Sep 1953 \\
HK & & 18 Sep 2002 & & Aug/Sep 1969 & & & \\
JAM & Oct 2006 & 16 Sep 2002 & Aug/Sep 1996 & & & \\
KWF & 23 Aug/9 Sep 2006 & 12 Sep 1997 & 18 Aug 1971 & Aug/Sep 1969 & & & \\
SSK & & 8 Aug 1998 & & Aug/Sep 1969 & & & \\
VF & 23 Aug/9 Sep 2006 & 12 Sep 1997 & & Aug/Sep 1969 & & & \\
\hline
\end{tabular}

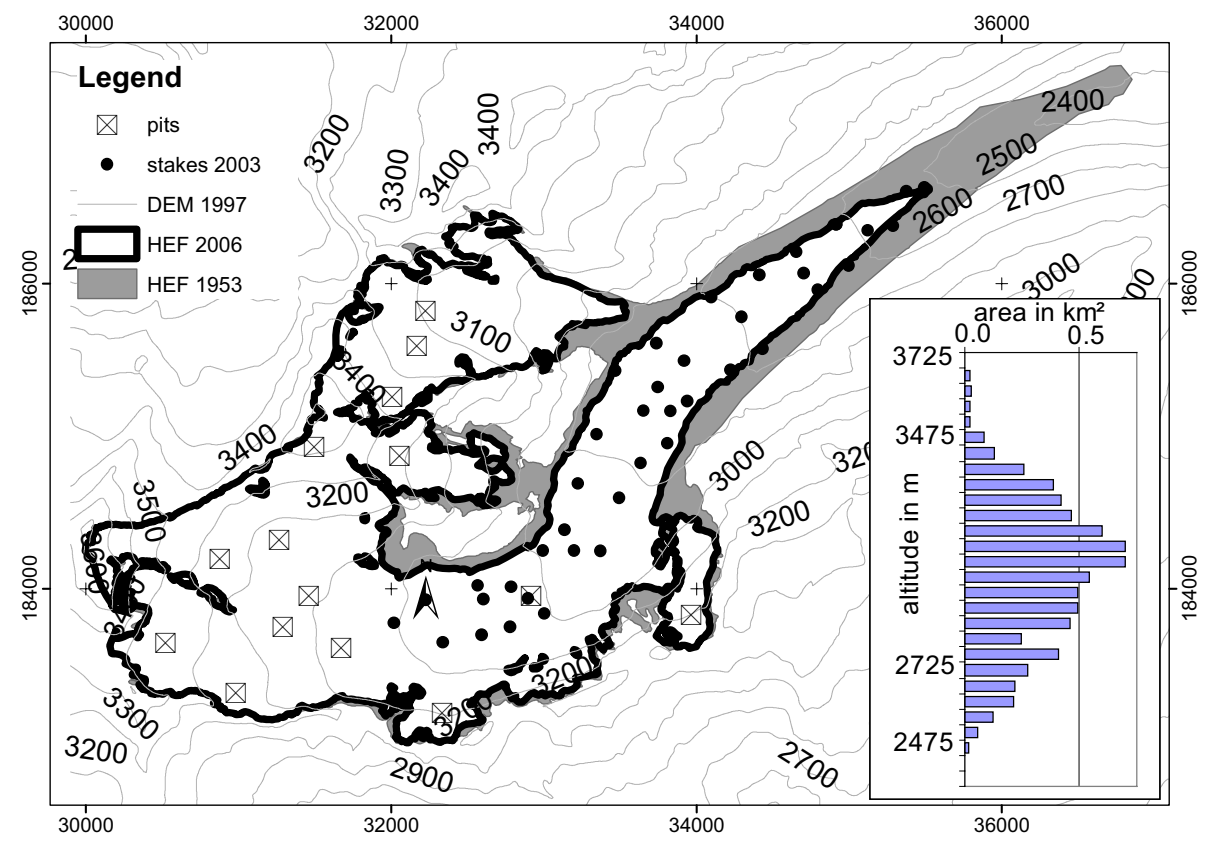

Fig. 5. Map of Hintereisferner, Ötztal Alps, with position of pits and stakes in 2003.

Adjacent Kesselwandferner (KWF) has about half of the area of Hintereisferner and has a smaller and higher ablation area (Fig. 6). The mass balance of KWF, which has also been measured since 1952/53, is therefore less negative than the mass balance of HEF. As shown by Kuhn et al. (1985), Hintereisferner and Kesselwandferner respond differently to climate variations.

The mass balance of nearby Vernagtferner (VF) has been measured since 1964/65 (Reinwarth and Escher-Vetter, 1999). The size of VF is similar to that of HEF, but the glacier type and topography differ. Vernagtferner also experienced a strong recession of the firn cover since 1964/65.

Übergossene Alm (HK) is a plateau glacier situated in the northeastern corner of Fig. 3 and located entirely below $3000 \mathrm{~m}$. The mass balance was measured by Goldberger (1986) between 1965 and 1996. The mass balance series ended in 1996, six years before 2002, when the the sec- ond DEM was acquired. Since the years from 1996 to 2002 brought further mass loss on HK, the direct data is a low estimate for the mass loss between 1969 and 2002.

The mass balance of Jamtalferner in Silvretta has been measured since 1989 (Fischer and Markl, 2008). The glacier is located between $2480 \mathrm{~m}$ a.s.l. and $3160 \mathrm{~m}$ a.s.l. The low elevation is explained by the large amount of accumulation relative to HEF, VF, and KWF. The size of JAM is similar to KWF.

Stubacher Sonnblickkees in Hohe Tauern has been measured since 1959 (Slupetzky, 1999). The Stubacher Sonnblickkees is a plateau glacier. It has about the same size as Übergossene Alm, but spans a wider range of elevations.

As indicated in Table 2, the DEMs were compiled with different techniques. Until 2003, the DEMS were compiled with terrestrial or airborne photogrammetry. Up to 1969 , the DEMs were compiled with terrestrial photogrammetry. The 


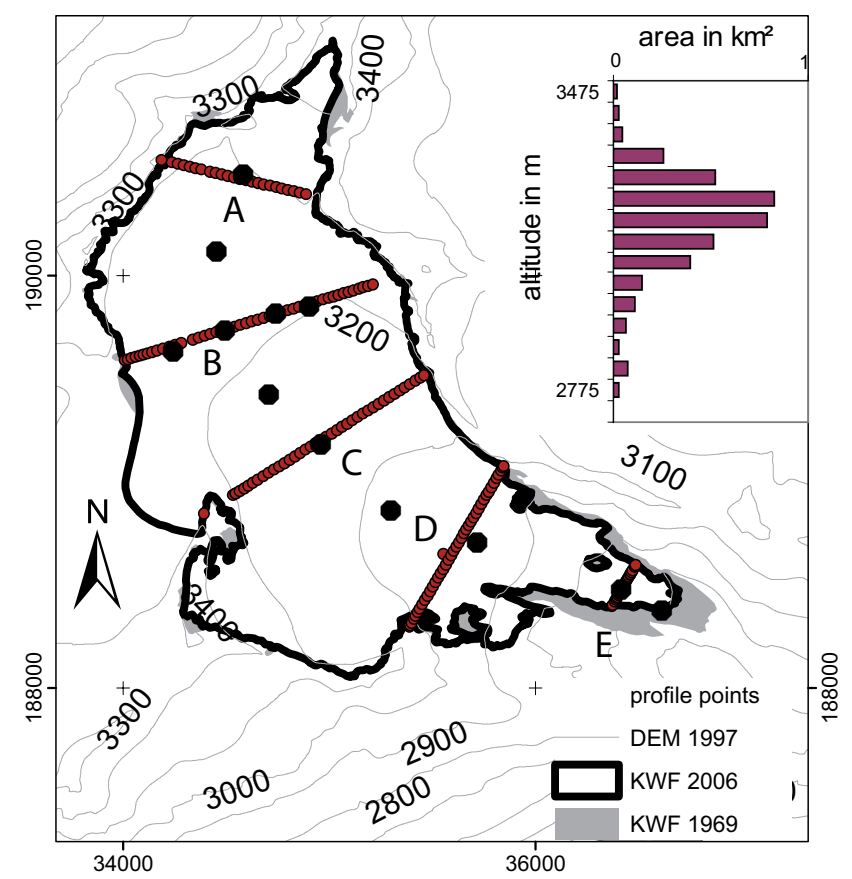

Fig. 6. Map of Kesselwandferner, Ötztal Alps, with profiles A to E (red dots) and position of stakes in 1997 (black dots).

DEMs used in this study dating from 2004 and later were acquired with airborne laser scanning. Improvements in methods for both the direct and the geodetic data have resulted in increasing accuracy over time.

\section{Results for six Austrian glaciers}

The glaciers show generally negative mass balances except between 1965 and 1969 and around 1980 (Fig. 7). The mean annual geodetic mass balance for all 19 periods of HEF, KWF, JAM, VF, and SSK between 1953 and 2006 is $-0.5 \mathrm{~m}$ w.e. $\mathrm{a}^{-1}$ (Table 3 ). The annual mean difference $b_{\text {geo }}-b_{\text {direct }}$ between the direct and the geodetic data is $-0.1 \mathrm{~m}$ w.e. $\mathrm{a}^{-1}$. The maximum difference $b_{\text {geo }}-b_{\text {direct }}$ is $5.6 \mathrm{~m}$ w.e., and the minimum $-7.0 \mathrm{~m}$ w.e. The average length of the time periods is $15.5 \mathrm{yr}$, the minimum is $2 \mathrm{yr}$ and the maximum 53 yr. On HEF, the geodetic mass balance differs from the direct by $-7.4 \mathrm{~m}$ w.e. for the total period $(53 \mathrm{yr})$. The geodetic mass balance for HEF gives an average of $0.14 \mathrm{~m}$ w.e. per year less than a medium year with direct data. On KWF (37 yr), the geodetic mass balance differs from the direct by $-2.2 \mathrm{~m}$ w.e. On SSK, JAM, and VF, the geodetic mass balance is greater than the direct, the difference is $+0.3 \mathrm{~m}$ w.e. for JAM, $+4.7 \mathrm{~m}$ w.e. for SSK, and $+0.6 \mathrm{~m}$ w.e. for VF ( $37 \mathrm{yr})$. For 9 time periods, the geodetic mass balance is greater than the direct, for 10 periods the direct mass balance is greater and in one period, the mass balances are equal.
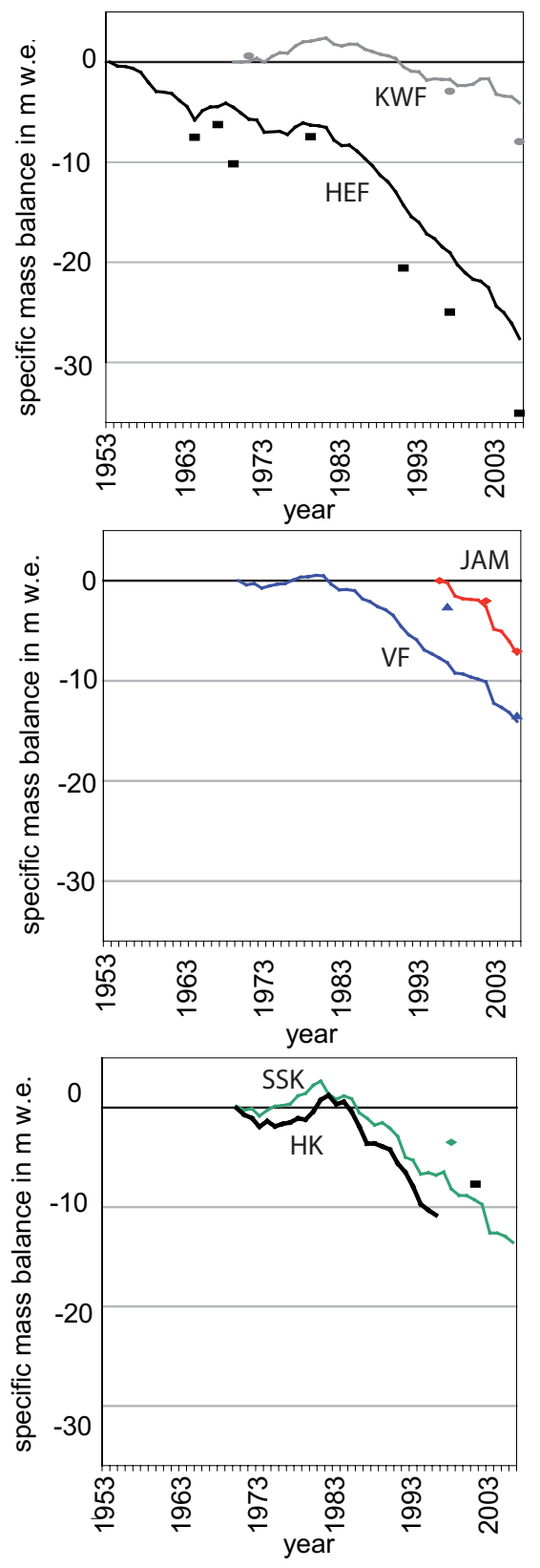

Fig. 7. Cumulative specific mass balance of HEF, KWF, VF, SSK, HK and JAM derived with the direct (lines) and the geodetic (dots) method.

The time series of the direct mass balance of HK ended in 1996, before the acquisition of the second DEM in 2002. The cumulative direct mass balance from 1969 to 1996 was $-10.8 \mathrm{~m}$; the geodetic mass balance from 1969 to 2002 was $-7.7 \mathrm{~m}$ (Table 3 ). Since the direct mass balance between 1997 and 2002 can be assumed to be negative, the direct mass balance is more negative than the geodetic mass balance by more than $3.1 \mathrm{~m}$. 
Table 3. Results of the cumulative specific mass balance for the geodetic $b_{\text {geo }}$ and the direct $b_{\text {direct }}$ method. The difference between the geodetic and the direct method is given in absolute numbers and divided by the number of years $N$. The numbers are rounded, the difference is calculated from the full values.

\begin{tabular}{|c|c|c|c|c|c|}
\hline $\begin{array}{l}\text { period } \\
\text { year }\end{array}$ & $\begin{array}{r}b_{\text {geo }} \\
\text { mw.e. }\end{array}$ & $\begin{array}{l}b_{\text {direct }} \\
\text { mw.e. }\end{array}$ & $\begin{array}{r}\Delta b \\
\text { m w.e. }\end{array}$ & $N$ & $\begin{array}{r}\Delta b / N \\
\text { mw.e. } \mathrm{a}^{-1}\end{array}$ \\
\hline \multicolumn{6}{|c|}{ Hintereisferner (HEF) } \\
\hline $1953-1964$ & -7.5 & -5.8 & -1.7 & 11 & -0.2 \\
\hline 1964-1967 & 1.3 & 1.3 & 0.0 & 3 & 0.0 \\
\hline 1967-1969 & -3.9 & -0.1 & -3.8 & 2 & -1.9 \\
\hline 1969-1979 & 2.7 & -1.8 & 4.5 & 10 & 0.5 \\
\hline 1979-1991 & -13.1 & -8.0 & -5.1 & 12 & -0.4 \\
\hline 1991-1997 & -4.4 & -4.7 & 0.3 & 6 & 0.1 \\
\hline 1997-2006 & -10.1 & -8.6 & -1.5 & 9 & -0.2 \\
\hline total & -35.0 & -27.7 & -7.3 & 53 & -0.1 \\
\hline \multicolumn{6}{|c|}{ Kesselwandferner (KWF) } \\
\hline 1969-1971 & 0.6 & 0.0 & 0.6 & 2 & 0.3 \\
\hline 1971-1997 & -3.5 & -1.7 & -1.8 & 26 & -0.1 \\
\hline 1997-2006 & -5.0 & -4.1 & -0.9 & 9 & -0.1 \\
\hline total & -7.9 & -5.8 & -2.1 & 37 & -0.1 \\
\hline \multicolumn{6}{|c|}{ Jamtalferner (JAM) } \\
\hline 1996-2002 & -2.0 & -2.6 & 0.6 & 6 & 0.1 \\
\hline 2002-2006 & -5.0 & -4.7 & -0.3 & 4 & -0.1 \\
\hline total & -7.0 & -7.3 & 0.3 & 10 & 0.0 \\
\hline \multicolumn{6}{|c|}{ Vernagtferner (VF) } \\
\hline 1969-1997 & -2.6 & -8.2 & 5.6 & 28 & 0.2 \\
\hline 1997-2006 & -10.9 & -5.833 & -5.1 & 9 & -0.6 \\
\hline total & -13.5 & -14.0 & 0.5 & 28 & 0.0 \\
\hline \multicolumn{6}{|c|}{ Stubacher Sonnblickkees (SSK) } \\
\hline $1969-1998$ & -3.5 & -8.2 & 4.7 & 29 & 0.2 \\
\hline \multicolumn{6}{|c|}{ Übergossene Alm. Hochkönig (HK) } \\
\hline $1969-1995$ & & -10.8 & & 33 & \\
\hline 1969-2002 & -7.7 & & & & \\
\hline
\end{tabular}

Figure 7 shows the cumulative direct mass balance and the cumulative geodetic mass balance for HEF, KWF, JAM, VF, SSK, and HK. For the glacier with the most negative mass balance, HEF, the cumulative geodetic mass balance is more negative than the direct. After years with positive mass balances (1965 to 1969 and 1977 to 1979), the geodetic mass balance (dots in Fig. 7) comes closer to the direct mass balance curve. The deviation of the curves increases with time and reaches its maximum in 2006 after several years with strong volume losses.

The mass balance of KWF for the observation period is the least negative of the investigated glaciers. From 1969

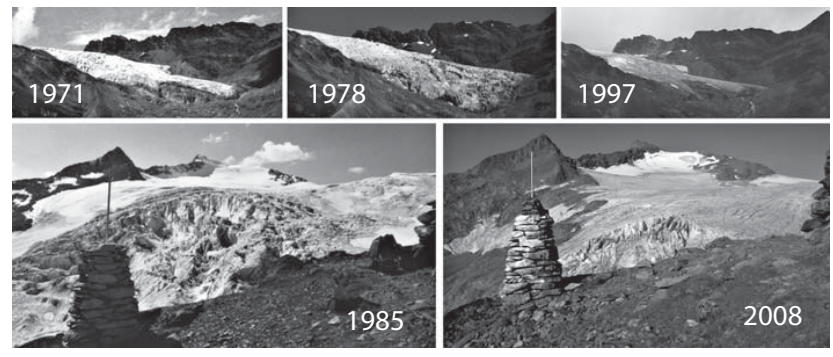

Fig. 8. The advance and retreat of the tongue of KWF in 1971, 1978 and 1995 with resulting changes in the upper part in 1985 and after slowing down in 2008 .

to 1971 , the geodetic mass balance is positive, whereas the directly measured mass balance is close to 0 . The geodetic mass balance is less negative than the direct mass balance for all subperiods. Between the 1971 DEM and the 1997 DEM the tongue of KWF advanced approximately $600 \mathrm{~m}$, then melted again. During the advance,the surface was very rough. Therefore the density at the tongue is lower than that of ice, since the crevasses included in the glacier volume of 1971 contain a lot of air (Fig. 8).

The adjacent glaciers VF and KWF were surveyed geodetically during the same periods: 1969-1997 and 19972006. From 1969 to 1997 , KWF ( -2.9 mw.e.) and VF $(-2.6 \mathrm{~m}$ w.e.) show a quite similar geodetic mass balance, but the direct mass balance of VF $(-8.2 \mathrm{mw}$ w.e.) is about 4 times the direct mass balance of KWF $(-1.7 \mathrm{~m}$ w.e.). At KWF, where the mass balance was close to zero, the difference between the geodetic and direct mass balance is small. On VF, where the mass balance was more negative, the differences between the direct and geodetic mass balance were larger. The observation period of SSK is comparable to that of VF and KWF (1969 to 1998); there the geodetic mass balance differs from the direct mass balance by $4.7 \mathrm{~m}$.

For JAM, the agreement between the geodetic and the direct data is very good for all periods. The glacier shows high accumulation rates, and is located at elevations below $3300 \mathrm{~m}$. The glacier tongue is small, and the firn cover shrank greatly after 2003 .

The difference between the direct and the geodetic mass balance is analyzed over all 19 periods to find if these differences also depend on the mass balance itself. Between 1965 and 1985, the direct mass balances $b_{\text {direct }}$ of HEF, KWF, JAM, VF, HK and SSK were more positive than before and after these years (Fig. 9). The geodetic data of this period are even more positive than the direct data. A possible reason for the discrepancy is the presence of seasonal snow cover on the glacier at the time of the second DEM, and its misinterpretation as less ice melt. From 1997 to 2006, most glaciers had strongly negative mass balances. During this time period, the geodetic mass balances are more negative than the direct. 


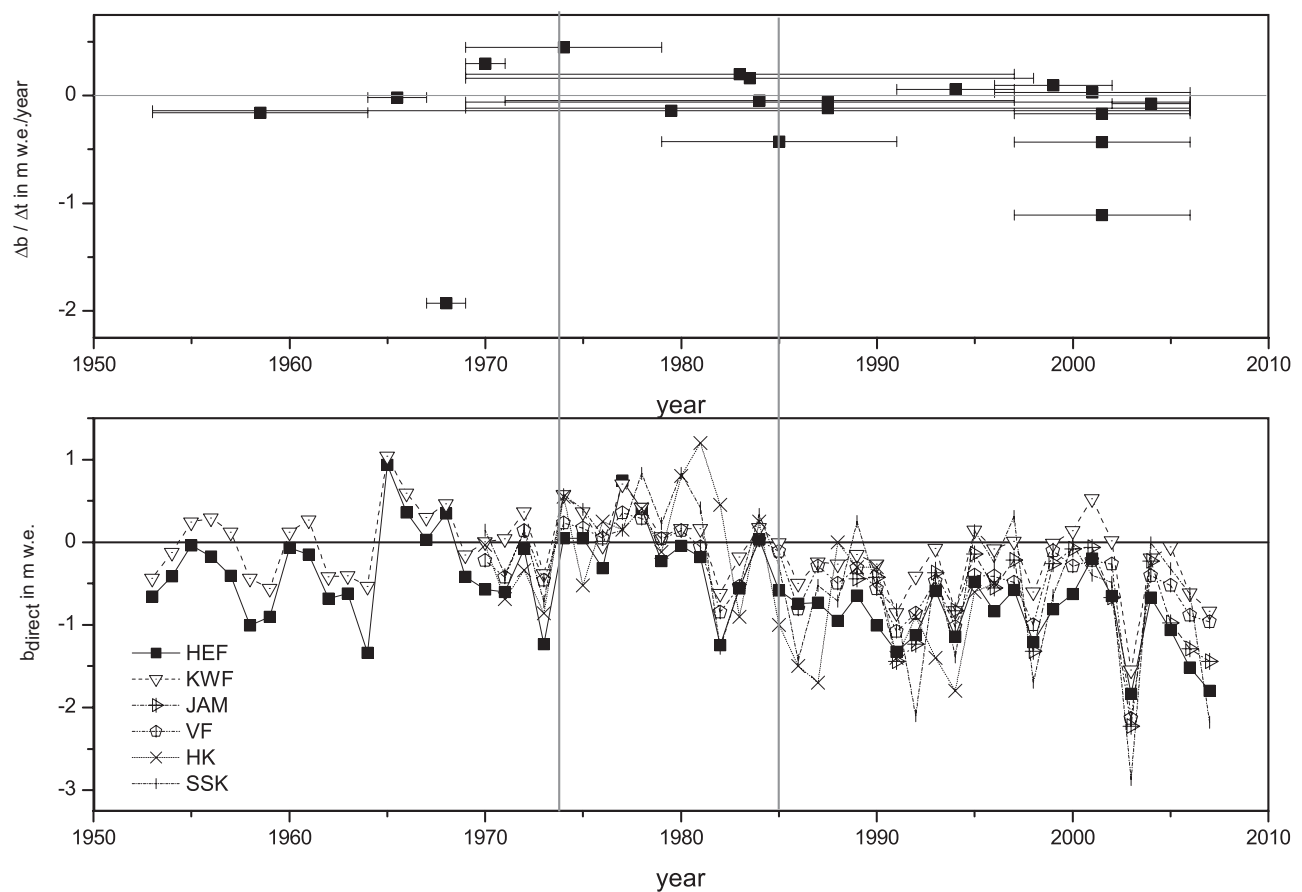

Fig. 9. Comparison of the difference between the geodetic and the direct mass balance per year $\Delta b / \Delta t$ and the direct specific mass balances $b_{\text {direct }}$. The length of the period of the geodetic mass balance mean is indicated with bars.

\section{Discussion}

\subsection{Accuracy of the DEMs}

The DEMs used here are acquired with different techniques listed in the order of increasing accuracy (Table 2):

Terrestrial photogrammetry: the topographic data before 1969 analyzed in this study were derived from old maps which are themselves based on terrestrial photogrammetry. The DEMs were digitized from the contour lines of orthorectified historical maps and processed to a raster with $5 \mathrm{~m}$ grid size using the Topo2raster tool of the ARCGis Software. The horizontal RMS errors of the rectified maps caused by drawing inaccuracies, changes of the map paper and coregistration are $\pm 1 \mathrm{~m}$. The accuracy of this elevation data depends on the imaging geometry and the location of the station points. Haggrén et al. (2007) reanalyzed the terrestrial photogrammetry data of Hochjochferner dating from 1907. From the comparison of the map of 1907 to the reanalyzed DEM they concluded that the terrestrial photogrammetric data has an accuracy of $\pm 10 \mathrm{~m}$. The tacheometrically surveyed glacier tongue showed an error of $\pm 1-2 \mathrm{~m}$.

Airborne photogrammetry: according to Würländer and Eder (1998), the accuracy of the airborne photogrammetric data used in this study is better than $\pm 0.71 \mathrm{~m}$. Lang and Patzelt (1971), reported that the accuracy of photogrammetric DEMs depends on the contrast of the images. All three glacier inventory datasets are available digitally, thus no ad- ditional referencing errors occurred during the digitalization of maps.

Airborne laser scanning: according to Høgda et al. (2007), the airborne laser scanning (LiDAR) technology allows the acquisition of DEMs with a vertical precision of a few $\mathrm{cm}$ independent of the texture and the contrast on the glacier surface. Geist and Stötter (2007) investigated LiDAR data on Hintereisferner and Kesselwandferner and found a relative vertical accuracy of $0.3 \mathrm{~m}$ and a relative horizontal accuracy of $1.0 \mathrm{~m}$. The point distance of LiDAR systems is $0.1 \mathrm{~m}$ to $1.4 \mathrm{~m}$, the pixel size $1 \mathrm{~m}$ to $2.5 \mathrm{~m}$.

For all kinds of digital topographic data, the absolute coregistration, the resolution, and the pixel sizes affect the vertical accuracy. The absolute horizontal accuracies of DEMs and coregistered historical data also depend on the availability of referenced tie points. Near Hintereisferner and Kesselwandferner, a net of geodetic fixed points installed from 1893 onwards ensured high accuracy (Fischer et al., 2011). Historical topographic data use different, and sometimes even local coordinate systems than contemporary DEMs. Thus coordinate transformations with appropriate parameters are necessary to avoid horizontal errors. Using standard transformation parameters, the horizontal error of the transformation between UTM WGS84 $32 \mathrm{~N}$ and GaussKrüger coordinates is up to several meters on HEF. The older maps of HEF are compiled in a local coordinate system with horizontal deviations of up to $4 \mathrm{~m}$ from the coordinates of the new maps (Abermann et al., 2007). Unfortunately, the 

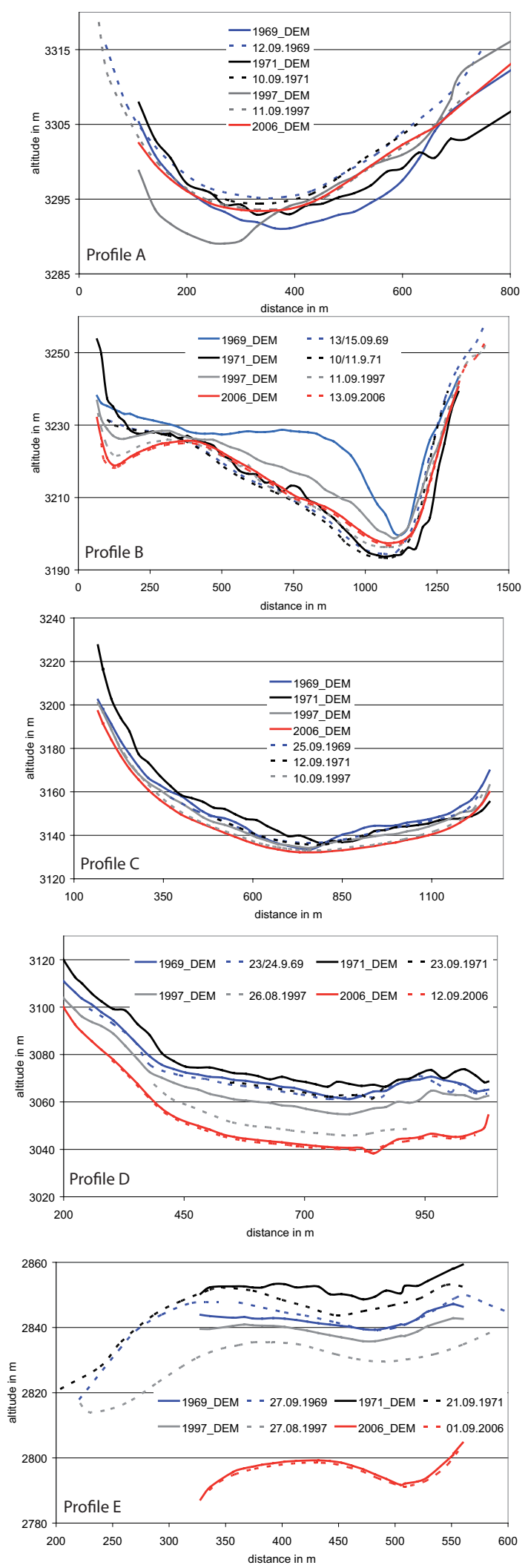

Fig. 10. Comparison between the elevation measured in the field along the profiles $\mathrm{A}$ to $\mathrm{E}$ at Kesselwandferner with the elevation in the DEMs of the specific year. original photogrammetric data of the older maps is not available, so that a reprocessing of the DEMs, as done by Koblet et al. (2010) for Storglaciären, is not possible. Therefore, other methods for qualitative spot tests of the DEMs were used. For Kesselwandferner, data from field surveys is available for every year. Since at least some of the ground control points (GCPs) surrounding the glacier might have been used for compiling the analogue maps, a comparison of the GCPs' coordinates makes little sense. But the comparison of the elevation data along the profiles A to E (Fig. 6) shows that local errors at the glacier can be significantly higher than the given accuracy (Abermann et al., 2007). The photogrammetric DEM of Kesselwandferner acquired in 1997 has low contrast in the firn area, resulting in an error of $>10 \mathrm{~m}$ in profile B (Fig. 10). The LiDAR DEM shows the best fit to the field data.

A plot of the relative frequency of the altitude differences (Fig. 11) shows that this distribution seems typical for the mass balance year, but also shows some errors in the DEMs. The volume change HEF 1964-1953 shows several areas with no volume change. These result from a small part at Langtaufererjochferner, where the terrestrial photogrammetry was not evaluated for 1964, and the gap was filled with the DEM 1953. Since most maps use older maps for compilation, this might not be an unusual case when working with historical maps. The frequency distribution of the volume changes of HK and SSK shows high noise; the differences containing LiDAR DEMs show low variability. This might be an easy to use visual indicator for the quality of the DEM, if there is no possibility to compare to field data.

\subsection{Different measurement dates and seasonal snow cover on Hintereisferner}

Seasonal snow cover is a potential source of error for the geodetic method. If seasonal snow cover is misinterpreted as ice, the glacier volume is overestimated. Depending on the time of the snow fall event, this results in either under- or overestimation of the geodetic mass balance. When no seasonal snow covers the glacier, the measured thickness change $h_{\mathrm{m}}$ corresponds to the ice thickness change $b_{\text {geo }}$. If the snow cover occurs during the acquisition of the first DEM, the ice thickness change is overestimated by $+\Delta h$. If the snow covers the glacier during the acquisition of the second DEM, the ice thickness change is underestimated by $-\Delta h$.

If one DEM within a time series $t_{1}, t_{2}$ and $t_{3}$ is affected by seasonal snow cover at $t_{2}$, the error balances out: $\Delta V_{t_{1} t_{2}}$ is for example too high and $\Delta V_{t_{2} t_{3}}$ too low. If the snow cover occurs at $t_{1}$ or $t_{3}$ the error extends over the entire period. Since the DEMs of 1969 are very likely affected by seasonal snow layers, the geodetic mass balances using the 1969 data as the second DEM are underestimated. The geodetic mass loss from 1969 to 1997 is likely to be overestimated, as is evident in Fig. 9. 

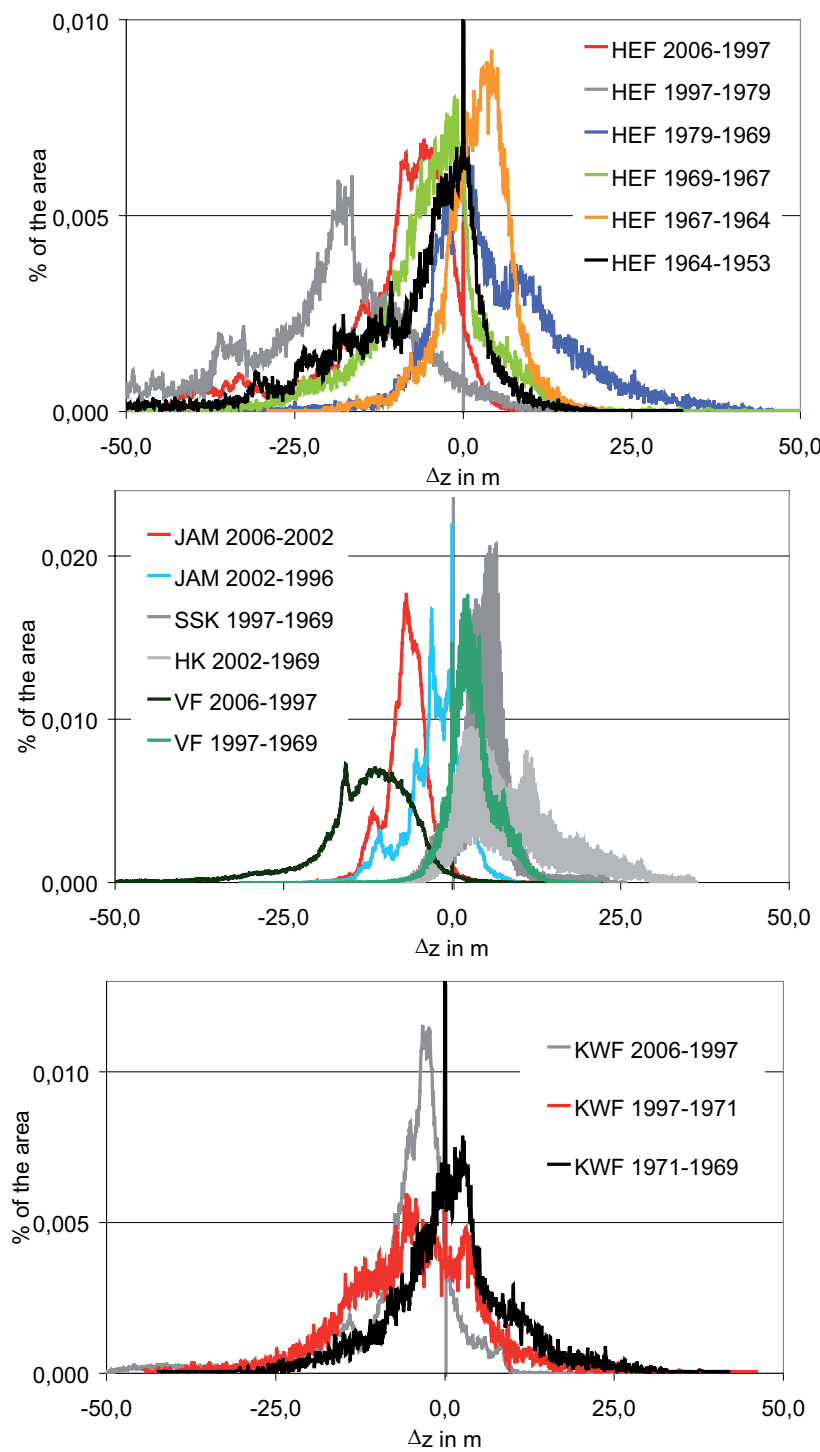

Fig. 11. Relative frequencies of values occurring in the calculated volume differences for the Austrian glaciers.

The density of the snow layer ranges from $100 \mathrm{~kg} \mathrm{~m}^{-3}$ to about $500 \mathrm{~kg} \mathrm{~m}^{-3}$, the density of ice is assumed to be $900 \mathrm{~kg} \mathrm{~m}^{-3}$. Thus within the period of the DEM acquisitions, the density of the surface layer can change by up to $800 \mathrm{~kg} \mathrm{~m}^{-3}$. A short example demonstrates the possible error of $b_{\text {geo }}$ : if a thickness change of $1 \mathrm{~m}$ of snow cover with a density of $500 \mathrm{~kg} \mathrm{~m}^{-3}(0.5 \mathrm{~m}$ w.e. $)$ is interpreted as a change of $1 \mathrm{~m}$ ice $(0.9 \mathrm{~m}$ w.e. $)$ instead, the error is $0.4 \mathrm{~m}$ w.e. The typical height of the winter snow cover on HEF ranges from $1-2 \mathrm{~m}$ on the glacier tongue to $5-7 \mathrm{~m}$ at the deepest snow pit. On Hallstätter glacier, winter snow cover with heights locally exceeding $10 \mathrm{~m}$ was observed. Snows in autumn (before 30 September) were observed to reach more than two meters on Hintereisferner and Hallstätter glacier; in August, snow cover may reach a height of $1.5 \mathrm{~m}$. Thus, seasonal snow

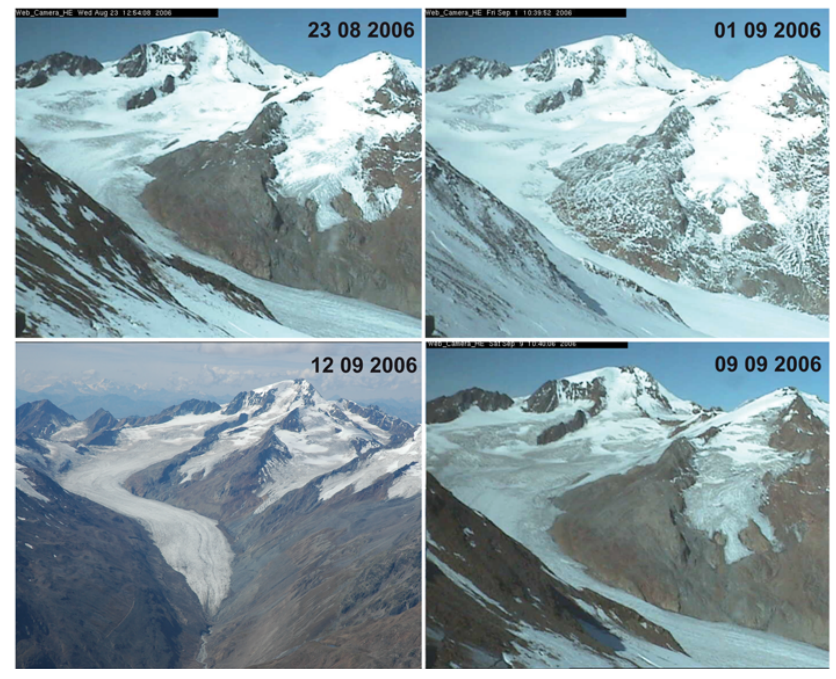

Fig. 12. Snow cover at $\mathrm{HEF}$ recorded by web cam images at $23 \mathrm{Au}-$ gust, 1 September, and 9 September 2006. The aerial image dates from 12 September 2006.

cover can result in errors of the same magnitude as the measured geodetic mass balance.

For the years 1969 to 2006, detailed records show ablation and accumulation at different altitudes on Hintereisferner:

August/September 1969: between 2 August and 30 September 1969, $2.17 \mathrm{~m}$ ice ablation took place at stake number 5 close to the tongue. At the 26 August $1969,0.17 \mathrm{~m}$ snow were recorded at that stake. At the highest stake in the firn area, between 1 August 1969 and 30 September 1969, $1.39 \mathrm{~m}$ firn ablation took place.

14/30 August 1979: no snow was recorded during the stake readings at 14 August, 23 August, 31 August 1979 between stake 1 at the tongue. $0.16 \mathrm{~m}$ of snow were recorded at 25 August 1979 at stake 54, which did not show ablation in the previous years.

12 September 1997: no seasonal snow covered the glacier.

23 August/9 September 2006: at the lowest stake (number 12), $0.98 \mathrm{~m}$ of ice melt were recorded between 24 August and 14 September 2006 . The tongue was not covered by snow, the upper parts of the glacier were partly covered by remnants of snow falls which occurred after the 28 August 2006 (Fig. 12)

Since the errors in the DEMs are likely to be of the same magnitude as the snow cover or melt, the effect on the geodetic mass balance was analyzed for 2001-2009 with highly accurate LiDAR data (Fischer et al., 2011) and not using photogrammetric DEMs.

\subsection{Density assumption and density changes}

Apart from the short term changes of surface layer density caused by seasonal snow cover, the mean density of the surface layer also changed during the last decades as a results 

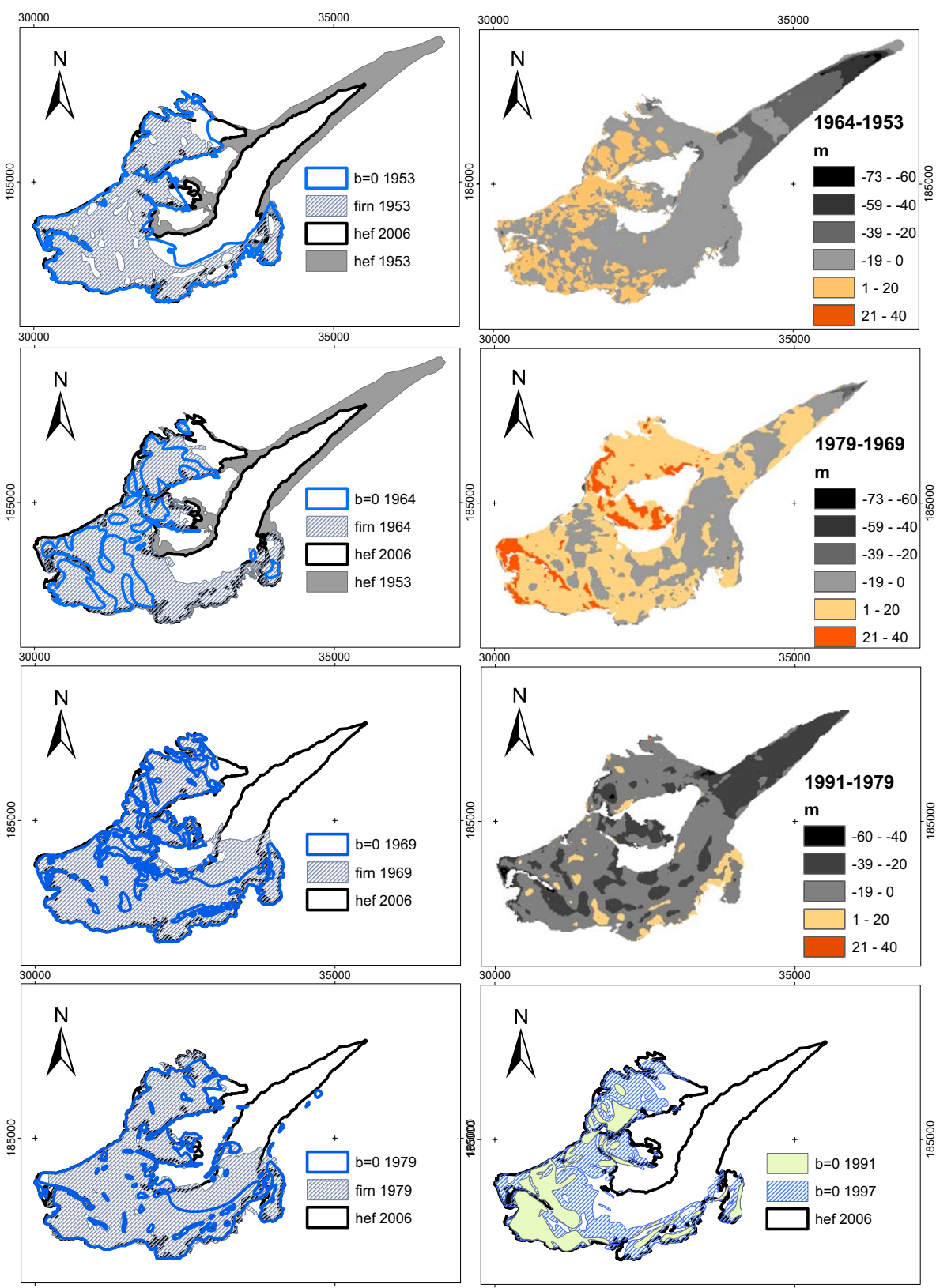

Fig. 13. Areas where $b=0$, firn covered area and volume change for different years where DEMs were recorded.

of strongly negative mass balances. Figure 13 shows the firn extent and the area covered with old snow for several years on HEF, when DEMs were recorded. It is evident that the accumulation area differs from the firn area and from the area with volume gain. Therefore, a volume gain or loss does not indicate a mass balance gain or loss at one specific location. As a result, the mean density for calculating the geodetic mass balance must come from a source other than the DEMs. The density of the annual layers close to the glacier surface varies significantly, as evident from the comparison of the zero mass balance line and the firn area in Fig. 13: snow can cover firn or ice, depending on the mass balance of the previous years and the ice dynamics. Over the course of several positive mass balance years, the tongue shows an thickness gain (1969-1979), because the vertical component of the ice flow velocity exceeds the mass balance. After 2000, the firn cover of Austria's glaciers dropped drastically, as shown for HEF by Fischer et al. (2011). The reduction of firn cover and the densification of firn layers and crevasses result in a misinterpretation of volume changes as mass changes. If the mean density of snow, firn, and ice decreases, the glacier surface drops without mass change. Another mechanism for a 

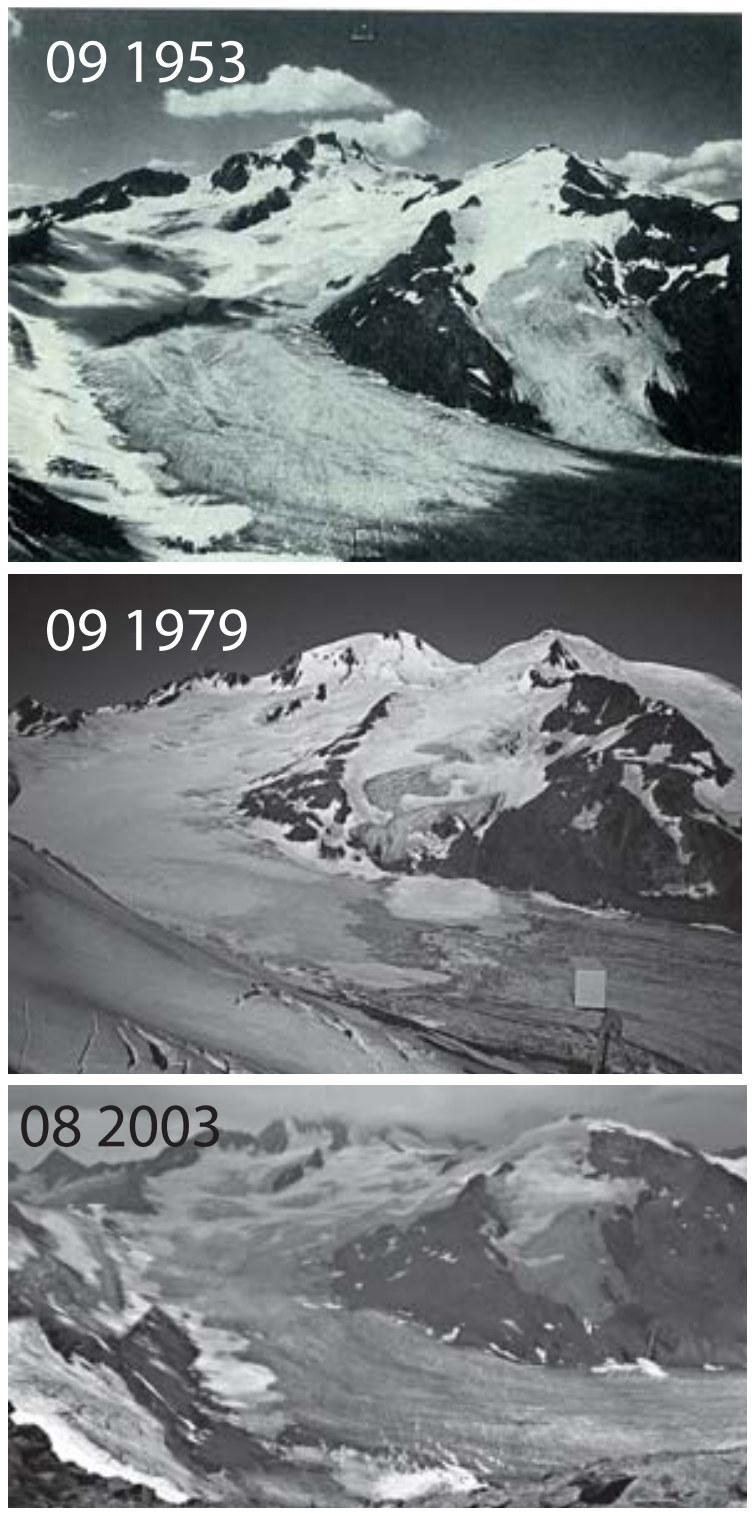

Fig. 14. Firn area of HEF in 1953, 1979 and 2003.

reduction in surface height without mass change is refreezing of melt water in a cold firn layer. Assuming the conservation of mass, fewer and smaller crevasses result in a lowering of the glacier surface. If the spatial resolution of the DEMs is high, crevasses can be visible if they are not covered with snow. In earlier datasets with lower resolution, crevasses are not included.

All Austrian glaciers experienced high amounts of accumulation in the 1960s and 1970s. Thus the mean density of the surface layer in the firn areas was lower than during the following years with strong negative mass balances. In 2003, even the highest glaciers in Austria lost most of their firn cover. Measurements on HEF showed a surface layer density of $800 \mathrm{~kg} \mathrm{~m}^{-3}$ at $3000 \mathrm{~m}$. Figure 14 is an example of the changes of the firn area at HEF. Between 1969 and 1997 and during the years of strong negative mass balances beginning with 2003, change in the density of the surface layer was observed.

A short example shows the possible contribution of densification to the total volume change of Austrian Alpine glaciers. Ambach et al. (1995) surveyed a $20 \mathrm{~m}$ deep firn pit on KWF and observed densities from $640 \mathrm{~kg} \mathrm{~m}^{-3}$ to $840 \mathrm{~kg} \mathrm{~m}^{-3}$. To estimate the effect of density changes within a firn column on the volume of the column, we calculate a small example. Assuming a firn column with $10 \mathrm{~m}$ height and a mean density of $750 \mathrm{~kg} \mathrm{~m}^{-3}$. A change of the mean density to $800 \mathrm{~kg} \mathrm{~m}^{-3}$ results in a thickness change of $0.6 \mathrm{~m}$. Another example for a density change without mass change could be the densification of the top layer in the firn area. Assuming a snow layer with a height of $1 \mathrm{~m}$ and a density of $200 \mathrm{~kg} \mathrm{~m}^{-3}$, the thickness of this layer can decrease by $0.5 \mathrm{~m}$ when the density increases to $400 \mathrm{~kg} \mathrm{~m}^{-3}$. Thus thickness changes resulting from densification are of the same order of magnitude as the mean annual thickness change of Austrian glaciers between 1969 and 1997 (Lambrecht and Kuhn, 2007).

Although the densification process plays a role mainly in the firn area, crevasses occur at all altitudes. Since the 1980s, the ice flow velocities reduced from over $100 \mathrm{~m}$ per year at several glaciers to just several $\mathrm{m}$ per year. Thus fewer and smaller crevasses are observed (Fig. 8). This effect alters the mean density of the glacier even in the ablation area. Very precise DEMs map crevasses, but low resolution photogrammetric maps or DEMs do not. If crevasses appear on newer DEMs, but not on the older ones, the volume loss is overestimated. If crevasses are covered with snow on the first LiDAR image, but not on the second LiDAR image, crevasse volume can contribute as much as 7\% to the volume change (Fischer et al., 2011).

\subsection{Basal or internal melt}

The geodetic mass balance includes basal or internal melt if the effects propagate to the glacier surface. The total change in surface elevation $\Delta h_{\mathrm{s}}$ results from internal $\Delta h_{\mathrm{i}}$ and basal ice thickness changes $\Delta h_{\mathrm{b}}$ (Fig. 15). In contrast, the direct mass balance is a surface mass balance and includes $\Delta h_{\mathrm{s}}$ only.

The development of Mittelbergferner (MBF) in the Ötztal Alps (Fig. 3) shows that locally the basal mass balance can contribute significantly to the volume change at the surface (Fig. 15). At an altitude of about $2500 \mathrm{~m}$ a.s.l. near the glacier margin, radial crevasses are surrounding a zone with fast subsidence (Fig. 16). The surface elevation dropped by $82 \mathrm{~m}$ in $9 \mathrm{yr}$. The annual ablation is less than $9.1 \mathrm{~m}$. The ice thickness above the subsidence zone is still 70 to $100 \mathrm{~m}$; the ice flow velocity is most likely nonzero. Therefore, the reason for the quick surface drop in this zone can only be basal melt. The high amounts of basal melt can be explained by 


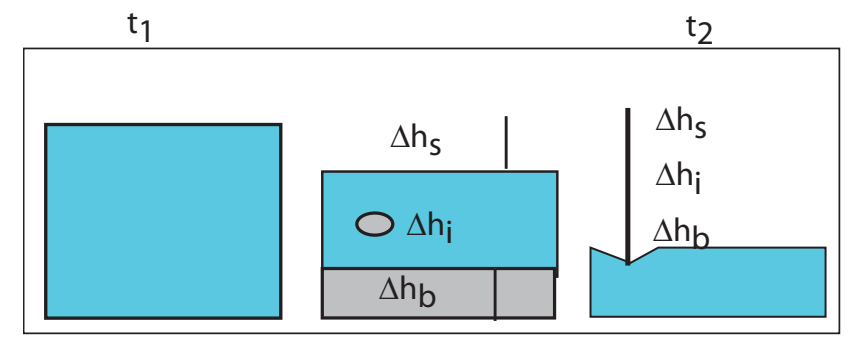

Fig. 15. The total thickness change of a glacier is caused by mass balance at the surface $\Delta h_{\mathrm{s}}$ and internal and basal mass balance $\Delta h_{\mathrm{i}}$ and $\Delta h_{\mathrm{b}}$ if the effects propagate to the surface.

two large melt water streams which join underneath the subsidence zone. Wiesenegger and Slupetzky (2009) made similar observations on Stubacher Sonnblickkees. Detailed measurements to quantify the effect for SSK, MBF, and HEF are ongoing.

\section{Comparison of the results to published data}

To find if the differences between the methods only occur in Austria, or also on glaciers in other regions and climates, the results are compared to published data. Griesgletscher (Funk et al., 1997), Gulkana glacier (Cox and March, 2004), Storglaciären (Zemp et al., 2010; Koblet et al., 2010), South Cascade Glacier (Krimmel, 1999), Lemon Creek glacier (Miller and Pelto, 1999), Storbreen (Andreassen, 1999) and Zongo glacier (Soruco et al., 2009) have been studied, and the geodetic and direct mass balance data is available for 26 time periods between 1940 and 2006. The average length of the periods is $18.2 \mathrm{yr}$ (Table 4). The longest period lasts $57 \mathrm{yr}$, the shortest $2 \mathrm{yr}$. The temporal distribution of the data is similar to that of the Austrian data. Where only the volume change without information on the mass balance or on the density of the surface layer was provided, the geodetic mass balance was calculated assuming a mean density of $850 \mathrm{~kg} \mathrm{~m}^{-3}$. The glaciers are located in different regions and different local climates, but the average annual geodetic mass balance is $-0.4 \mathrm{~m}$ w.e. $\mathrm{a}^{-1}$ and thus similar to the mean of the Austrian data $\left(-0.5 \mathrm{~m}\right.$ w.e. $\left.\mathrm{a}^{-1}\right)$. The mean difference is $-0.4 \mathrm{~m}$ w.e., the maximum difference $3.6 \mathrm{~m}$ w.e. and the minimum difference $-7.2 \mathrm{~m}$ w.e.

The data of Storbreen confirm the finding that a longer measurement period length does not automatically result in more agreement between the geodetic and the direct mass balances (Fig. 17). Just like the Austrian glaciers, Storglaciären, South Cascade, and Lemon Creek show higher differences during periods with strongly negative mass balances. This is not the case for Storbreen and Griesgletscher.

Figure 18 is a plot of the geodetic vs. the direct mass balance. As stated by Cogley (2009), no common trend for all glaciers is obvious. Some glaciers do show trends, which are

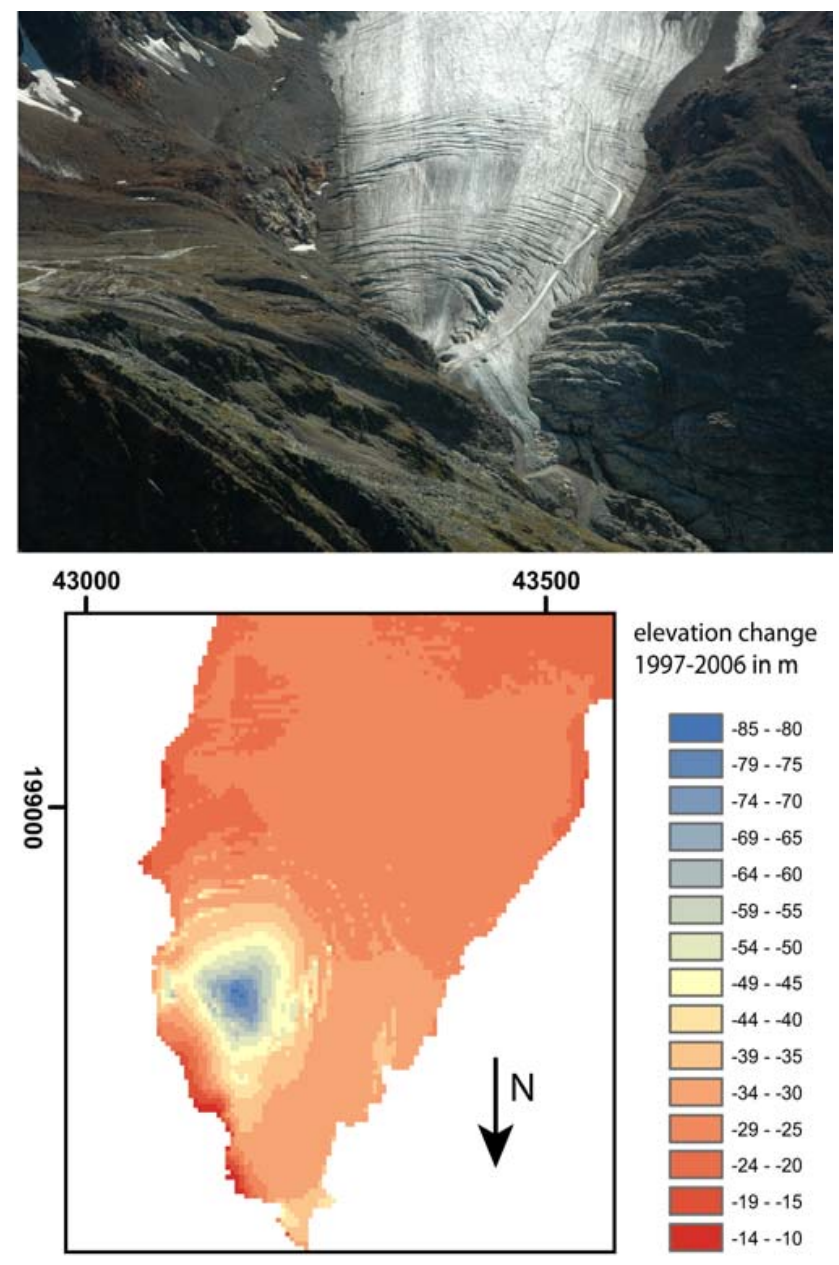

Fig. 16. Radial crevasses and subsidence zone at the tongue of Mittelbergferner in 2006 and the surface elevation change in $\mathrm{m}$ between 1997 and 2006.

related to the specific properties of the glacier. For example on HEF the geodetic mass balance is more negative than other mass balances. The more negative the mass balances, the greater the differences. This is caused by glacier topography: melt water from the entire glacier area flows underneath the pronounced glacier tongue of this valley glacier. On Jamtalferner, the difference between direct and geodetic data shows nearly no trend, which could also be caused by compensation of different processes. Lemon Creek and South Cascade glacier show trends opposite to that of HEF: the geodetic mass balances are increasingly less negative than the direct. For South Cascade glacier, Krimmel (1999) points out that the direct mass balance is too negative. South cascade glacier shows a correlation of 0.80 and higher with all 13 monitored glacier within $150 \mathrm{~km}$, but has the most negative mean annual balance of all of these glaciers (Pelto and Riedel, 2001). For Lemon Creek glacier, (Miller and Pelto, 1999) found that the errors in the assessment of the mass balance mainly take place at the glacier tongue. They state 
Table 4. Results of the cumulative specific mass balance for the geodetic $b_{\text {geo }}$ and the direct $b_{\text {direct }}$ method. The difference between the geodetic and the direct method is given in absolute numbers and divided by the number of years $N$. The numbers are rounded, the difference is calculated from the full values. ${ }^{*}$ - calculation from volume change assuming a density of $850 \mathrm{~kg} \mathrm{~m}^{-3}$.

\begin{tabular}{|c|c|c|c|c|c|}
\hline $\begin{array}{l}\text { period } \\
\text { year }\end{array}$ & $\begin{array}{r}b_{\text {geo }} \\
\text { mw.e. }\end{array}$ & $\begin{array}{l}b_{\text {direct }} \\
\text { m w.e. }\end{array}$ & $\begin{array}{r}\Delta b \\
\text { m w.e. }\end{array}$ & $N$ & $\begin{array}{r}\Delta b / N \\
\text { m w.e. } \mathrm{a}^{-1}\end{array}$ \\
\hline \multicolumn{6}{|c|}{ Griesgletscher GG (Funk et al., 1997) } \\
\hline 1961-1979 & -1.7 & -1.1 & -0.6 & 18 & 0.0 \\
\hline 1979-1986 & -2.1 & -0.3 & -1.8 & 7 & -0.3 \\
\hline 1986-1991 & -5.1 & -1.0 & -4.1 & 5 & -0.8 \\
\hline total & -8.9 & -2.4 & -6.5 & 30 & -0.2 \\
\hline \multicolumn{6}{|c|}{ Gulkana Glacier GU (Cox and March, 2004) } \\
\hline 1974-1993 & -6.0 & -5.8 & -0.2 & 19 & 0.0 \\
\hline 1974-1999 & -11.8 & -11.2 & -0.6 & 25 & 0.0 \\
\hline \multicolumn{6}{|c|}{ Lemon Creek LC (Miller and Pelto, 1999) } \\
\hline 1957-1989 & -11.2 & -12.7 & 1.5 & 32 & 0.0 \\
\hline 1957-1995 & -13.9 & -17.1 & 3.2 & 38 & 0.1 \\
\hline total & -18.4 & -22.0 & 3.6 & 41 & 0.1 \\
\hline \multicolumn{6}{|c|}{ South Cascade SC (Krimmel, 1999)* } \\
\hline 1970-1975 & 0.8 & 2.4 & -1.6 & 5 & -0.3 \\
\hline 1975-1977 & -0.4 & -1.6 & 1.2 & 2 & 0.6 \\
\hline 1977-1979 & -1.9 & -1.4 & -0.5 & 2 & -0.3 \\
\hline 1979-1985 & -3.6 & -5.7 & 2.1 & 6 & 0.4 \\
\hline 1985-1997 & -11.4 & -12.7 & 1.3 & 12 & 0.1 \\
\hline total & -16.5 & -19.0 & 2.5 & 27 & 0.1 \\
\hline \multicolumn{6}{|c|}{ Storbreen SB (Andreassen, 1999) } \\
\hline 1940-1951 & -6.4 & -4.9 & -1.5 & 11 & -0.1 \\
\hline 1951-1968 & -4.6 & -1.3 & -3.3 & 17 & -0.2 \\
\hline 1968-1984 & -5.1 & -5.4 & 0.3 & 16 & 0.0 \\
\hline 1984-1997 & -0.7 & 2.0 & -2.7 & 13 & -0.2 \\
\hline total & -16.8 & -9.6 & -7.2 & 57 & -0.1 \\
\hline
\end{tabular}

Storglaciären SG (Zemp et al., 2010)

\begin{tabular}{lrrrrr}
\hline $1959-1969$ & -3.9 & -3.1 & -0.8 & 10 & -0.1 \\
$1969-1980$ & -2.8 & -2.5 & -0.3 & 11 & 0.0 \\
$1980-1990$ & 1.3 & 1.0 & 0.3 & 10 & 0.0 \\
$1990-1999$ & 0.6 & 0.7 & -0.1 & 9 & 0.0 \\
total & -4.8 & -3.9 & -0.9 & 40 & 0.0 \\
\hline
\end{tabular}

Zongo Glacier ZG (Soruco et al., 2009)

\begin{tabular}{llllll}
\hline $1997-2006$ & -5.1 & -7.5 & 2.4 & 9 & 0.3 \\
\hline
\end{tabular}

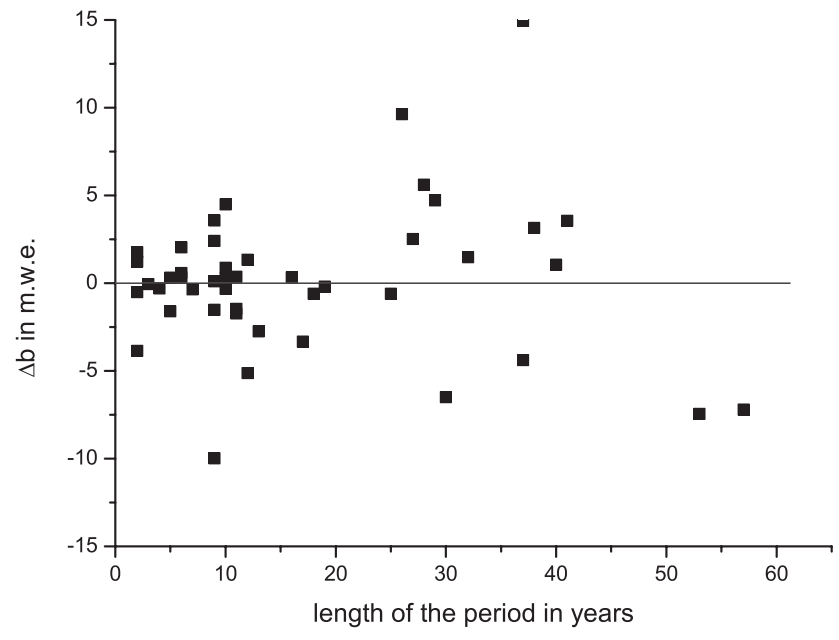

Fig. 17. Length of the period for which the geodetic mass balance $b_{\text {geo }}$ is calculated vs. the difference $\Delta b$ between the geodetic and the direct mass balance.

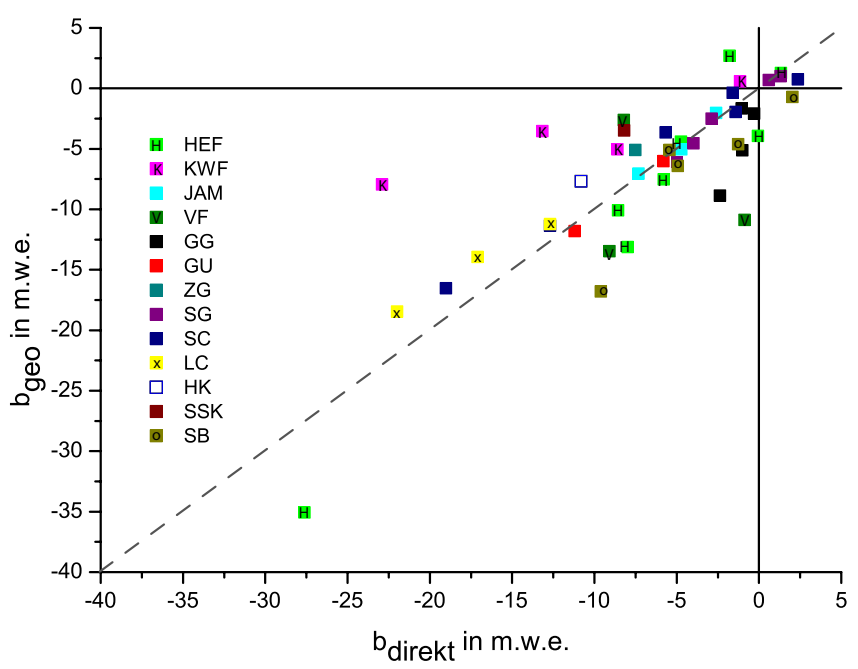

Fig. 18. Comparison of the geodetic $b_{\text {geo }}$ and direct $b_{\text {direct }}$ mass balance for all 12 glaciers. Griesgletscher - GG, Gulkana Glacier GU, Zongo Glacier - ZG, Storglaciären - SG, South Cascade - SC, Lemon Creek - LC.

that the reasons for these errors are that the glacier area is not annually updated and that accuracy of the ablation data decreases with distance from the glacier tongue.

The accuracy of the direct data is $\pm 0.01 \mathrm{~m}$ w.e. $\mathrm{a}^{-1}$. Assuming a period of $10 \mathrm{yr}$, the mean accuracy of the geodetic method on Austrian Alpine glaciers is limited by densification $\left( \pm 0.1 \mathrm{mw}\right.$ w.e. $\left.\mathrm{a}^{-1}\right)$, seasonal snow cover $\left( \pm 0.1 \mathrm{~m}\right.$ w.e. $\left.\mathrm{a}^{-1}\right)$, and basal melt $\left(0.5 \mathrm{~m}\right.$ w.e. $\left.\mathrm{a}^{-1}\right)$, as well as the accuracy of the DEMs. Terrestrial photogrammetric DEMs with good coregistration in our example show errors of $1.0 \mathrm{~m} \mathrm{a}^{-1}$; LiDAR DEMs have errors of $0.001 \mathrm{~m} \mathrm{a}^{-1}$ for the $10 \mathrm{yr}$ period. The uncertainty of at least $\pm 50 \mathrm{~kg} \mathrm{~m}^{-3}$ in 
the mean density adds $10 \%$ error to the geodetic mass balance which then is $1.0 \mathrm{~m}$ w.e. $\mathrm{a}^{-1}$ and $0.001 \mathrm{~m}$ w.e. $\mathrm{a}^{-1}$, respectively. Thus the cumulative error of the geodetic mass balance is $2.7 \mathrm{~m}$ w.e. $\mathrm{a}^{-1}$ for two terrestrial photogrammetric DEMs, and $0.702 \mathrm{~m}$ w.e. $\mathrm{a}^{-1}$ for two LiDAR DEMs. For historical data, the errors of the DEMs dominate the total error, whereas for LiDAR data glaciological processes dominate. The time period for the calculation of geodetic data should be chosen in relation to the total mass balance to ensure that the mass balance within this period is significantly larger than the error values.

\section{Conclusions}

The direct and the geodetic mass balances differ. On some glaciers, the discrepancy shows a trend, on others, it does not. For some glaciers, area changes are reported to be the reason for the deviation. This was not the case for HEF, JAM, and KWF. It is possible that geodetic and direct data differ as a result of processes such as basal and internal mass changes, which are shown to locally contribute significantly to the total mass change on the tongue of Mittelbergferner. The mean density of the volume changes varies in time and space. The best agreement between the geodetic and the direct mass balance therefore is expected for glaciers in equilibrium. For real glaciers, the determination of a mean density for the volume change is not straight forward, even with the help of direct mass balance data, which might be the main uncertainty in the geodetic method. The differences between the direct and the geodetic data increase with increasing negative mass balances for most investigated glaciers. For Austria, the differences show trends likely related to glacier state and glacier type. The investigated Austrian glaciers with less negative mass balances receive a higher amount of accumulation and show smaller differences between geodetic and direct data. The largest differences are observed during periods with strong negative mass balances, when the basal melt caused by the subglacial melt water streams is expected to be high.

The accuracy of the geodetic data in Alpine regions ranges from $2.7 \mathrm{~m}$ for terrestrial photogrammetric data and $0.7 \mathrm{~m}$ for the LiDAR data. Errors in the coregistration, different pixel sizes of the DEMs, shadows, and oversaturation of photogrammetric images increase the total error.

The comparison of the difference between the geodetic and the direct method with the length of the observation period shows that longer observation periods do not necessarily reduce the difference between the geodetic and the direct mass balance.

In summary, the results show that the geodetic and the direct glaciological method are not only different ways to measure the same parameter, but map different processes. On one hand, the inclusion of intra- and subglacial melt, when these result in elevation changes, is a clear advantage for the geodetic data to estimate the contribution of glaciers to global sea level rise. On the other hand, the geodetic method can be easily biased by seasonal snow cover and missing information about density, including not only the surface layer, but also density changes as result of intra- and subglacial melt or crevasses. The direct mass balance measures the surface mass balance with high accuracy and high temporal resolution, while the temporal resolution of the geodetic data is limited by the errors of up to $2.7 \mathrm{~m}$ w.e. During periods of high melt rates, the reduction and densification of firn cover biases the geodetic mass balance.

Direct and geodetic mass balance are both valuable tools for different applications. They contain specific, but different, information on glacier mass balance. A mix of direct and geodetic data should be handled with caution. To avoid biases in long time series of mass balance data, the method of measurement should remain constant.

Acknowledgements. First of all, I want to acknowledge all the people who contributed to the data sets and helped the time series to exist for that many decades. The study was funded by the Herta-Firnberg Grant ZFT 3290 of the Austrian Science Foundation (FWF). The field work on Hintereisferner, Kesselwandferner, and Jamtalferner and the acquisition of the glacier inventories of 1969 and 1998 were supported by the Hydrographical survey of the federal government of Tyrol and the Commission of Geophysical Research of the Austrian Academy of Sciences. The DEMs 2004 to 2006 for the third Austrian glacier inventory were provided by the Federal government of Tyrol. The mass balance data of Vernagtferner was kindly provided by the Commission for Glaciology of the Bavarian Academy of Sciences and Humanities. I want to thank H. Slupetzky for providing the mass balance data of Stubacher Sonnblickkees, which was supported by the Hydrographical Survey of the Government of Salzburg. The comments of Michael Zemp, Andreas Kääb, Mauri Pelto and Emmanuel Thibert helped to substantially improve the paper.

Edited by: A. Kääb

\section{References}

Abermann, J., Schneider, H., and Lambrecht, A.: Analysis of surface elevation changes on Kesselwand glacier - comparison of different methods, Zeitschrift für Gletscherkunde und Glazialgeologie, 41, 147-167, 2007.

Abermann, J., Lambrecht, A., Fischer, A., and Kuhn, M.: Quantifying changes and trends in glacier area and volume in the Austrian Ötztal Alps (1969-1997-2006), The Cryosphere, 3, 205215, doi:10.5194/tc-3-205-2009, 2009.

Ahlmann, H.: Glaciological Research on the North Atlantic Coasts, no. 1 in Royal Geographical Society, Research Series, 1948.

Ambach, W., Huber, J., Eisner, H., and Schneider, H.: Depth profiles of effective viscosities of temperate firn following from strain rate measurements at two firn pits (Kesselwandferner, Oetztal Alps, 1967-1989), Cold Reg. Sci. Technol., 23(8), 257264, available at: http://www.ingentaconnect.com/content/els/ 0165232x/1995/00000023/00000003/art00017, 1995. 
Andreassen, L.: Comparing Traditional Mass Balance Measurements with Long-term Volume Change Extracted from Topographical Maps: A Case Ctudy for Storbreen Glacier in Jotunheimen, Norway, for the Period 1940-1997, Geogr. Ann. A, 81A, 467-475, 1999.

Braithwaite, R. J.: Glacier mass balance: the first 50 years of international monitoring, Prog. Phys. Geog., 26, 76-95, doi:10.1191/0309133302pp326ra, 2002.

Cogley, J.: Geodetic and direct mass-balance measurements: comparison and joint analysis, Ann. Glaciol., 50(50), 96-100, 2009.

Cox, L. H. and March, R. S.: Comparison of geodetic and glaciological mass-balance techniques, Gulkana Glacier, Alaska, USA, J. Glaciol., 50(8), 363-370, doi:10.3189/172756504781829855, 2004.

Finsterwalder, R.: Die zahlenmäßige Erfassung des Gletscherrückgangs an Ostalpengletschern, Zeitschrift für Gletscherkunde und Glazialgeologie, 2, 189-239, 1953.

Finsterwalder, S.: Die Gletscherbewegung mit Berücksichtigung ihres senkrechten Anteils, Zeitschrift für Gletscherkunde, 1, 420, 1907.

Fischer, A.: Glaciers and climate change: Interpretation of 50years of direct mass balance of Hintereisferner, Global Planet. Change, 71, 13-26, doi:10.1016/j.gloplacha.2009.11.014, 2010.

Fischer, A. and Markl, G.: Mass balance measurements on Hintereisferner, Kesselwandferner, and Jamtalferner 2003 to 2006. Database and results, Zeitschrift für Gletscherkunde und Glazialgeologie, 42, 47-83, 2008.

Fischer, A., Schneider, H., Merkel, G., and Sailer, R.: Comparison of direct and geodetic mass balances on an annual time scale, The Cryosphere Discuss., 5, 565-604, doi:10.5194/tcd-5-565-2011, 2011

Fountain, A. G. and Vecchia, A.: How Many Stakes Are Required to Measure the Mass Balance of a Glacier?, Geogr. Ann. A, 81, 563-573, available at: http://www.jstor.org/stable/521494, 1999.

Funk, M., Morelli, R., and Stahel, W.: Mass balance of Griesgletscher 1961-1994: different methods of determination, Zeitschrift für Gletscherkunde und Glazialgeologie, 33, 41-55, 1997.

Geist, T. and Stötter, J.: Documentation of glacier surface elevation change with multitemporal airborne laser scanner data case study: Hintereisferner and Kesselwandferner, Tyrol, Austria, Zeitschrift für Gletscherkunde und Glazialgeologie, 41, 77106, 2007.

Goldberger, J.: Gletscherhaushalt und klimatische Umwelt des Hochköniggletschers 1965-1975, Wissenschaftliche Alpenvereinshefte, 79 pp., 1986.

Gross, G.: Der Flächenverlust der Gletscher in Österreich 18501920-1969, Zeitschrift für Gletscherkunde und Glazialgeologie, 23, 131-141, 1987.

Hagg, W., Braun, L., Uvarov, V., and Makarevich, K.: A comparison of three methods of mass balance determination in the Tuyuksu glacier region, Tien Shan, Central Asia, J. Glaciol., 50, 505-510, 2004.

Haggrén, C., Mayer, C., Nuikka, M., Braun, L., Rentsch, H., and Peipe, J.: Processing of old terrestrial photography for verifying the 1907 digital elevation model of Hochjochferner glacier, Zeitschrift für Gletscherkunde und Glazialgeologie, 41, 29-35, 2007.

Hess, H.: Die Gletscher, F. Vieweg and Son, Braunschweig, 1904.
Høgda, K., Geist, T., and Jackson, M.: Comparison of digital elevation models of Engabreen glacier, Zeitschrift für Gletscherkunde und Glazialgeologie, 41, 185-204, 2007.

Hoinkes, H.: Methoden und Möglichkeiten von Massenhaushaltsstudien auf Gletschern, Zeitschrift für Gletscherkunde und Glazialgeologie, 6, 37-90, 1970.

Huss, M., Bauder, A., and Funk, M.: Homogenization of longterm mass-balance time series, Ann. Glaciol., 50(9), 198-206, doi:10.3189/172756409787769627, 2009.

Jacobsen, F. M. and Theakstone, W. H.: The use of planimetric surface area in glacier mass-balance calculations: a potential source of errors, J. Glaciol., 41, 441-444, 1995.

Jacobsen, F. and Theakstone, W.: A reply to comments on by G. Kaser on "The use of planimetric surface area in glacier massbalance calculations: a potential source of errors", J. Glaciol., 42, p. 588, 1996.

Jansson, P.: Effect of uncertainties in measured variables on the calculated mass balance of Storglaciären, Geogr. Ann. A, 81A, 633-642, 1999.

Jarvis, A., Reuter, H., Nelson, A., and Guevara, E.: Hole-filled seamless SRTM data V3, International Centre for Tropical Agriculture (CIAT), http://srtm.csi.cgiar.org, 2008.

Kaser, G.: Comments on "The use of planimetric surface area in glacier mass-balance calculations: a potential source of errors" by Jacobsen and Theakstone, J. Glaciol., 42, p. 589, 1996.

Kaser, G., Cogley, J., Dyurgerov, M., Meier, M., and Ohmura, A.: Mass balance of glaciers and ice caps: Consensus estimates for 1961-2004, Geophys. Res. Lett., 33, 19501, doi:10.1029/2006GL027511, 2006.

Koblet, T., Gärtner-Roer, I., Zemp, M., Jansson, P., Thee, P., Haeberli, W., and Holmlund, P.: Reanalysis of multi-temporal aerial images of Storglaciren, Sweden (1959-99) - Part 1: Determination of length, area, and volume changes, The Cryosphere, 4, 333-343, doi:10.5194/tc-4-333-2010, 2010.

Krimmel, R. M.: Analysis of Difference between Direct and Geodetic Mass Balance Measurements at South Cascade Glacier, Washington, Geogr. Ann. A, 81(4), 653-658, 1999.

Kuhn, M.: Begleitworte zur Karte des Hintereisferners 1979, 1:10000, Zeitschrift für Gletscherkunde und Glazialgeologie, 16, 117-124, 1979.

Kuhn, M., Markl, G., Kaser, G., Nickus, U., Obleitner, F., and Schneider, H.: Fluctuations of climate and mass balance: different responses of two adjacent glaciers, Zeitschrift für Gletscherkunde und Glazialgeologie, 21, 409-416, 1985.

Kuhn, M., Dreiseitl, E., Hofinger, S., Markl, G., Span, N., and Kaser, G.: Measurements and models of the mass balance of Hintereisferner, Geogr. Ann. A, 81A, 659-670, 1999.

Lambrecht, A. and Kuhn, M.: Glacier changes in the Austrian Alps during the last three decades, derived from the new Austrian glacier inventory, Ann. Glaciol., 46, 177-184, 2007.

Lang, H. and Patzelt, G.: Die Volumenänderungen des Hintereisferners (Ötztaler Alpen) im Vergleich zur Massenänderung im Zeitraum 1953-64, Zeitschrift für Gletscherkunde und Glazialgeologie, 7(1-2), 229-238, 1971.

Lemke, P., Ren, J., Alley, R., Allison, I., Carrasco, J., Flato, G., Fujii, Y., Kaser, G., Mote, P., Thomas, R., and Zhang, T.: Climate Change: The Physical Science Basis. Contribution of Working Group I to the Fourth Assessment Report of the Intergovernmental Panel on Climate Change, chap. Observations: Changes 
in Snow, Ice and Frozen Ground, Cambridge University Press, Cambridge, United Kingdom and New York, 2007.

Meier, M.: Proposed definitions for glacier mass budget terms, J. Glaciol., 4, 252-265, 1962.

Miller, M. M. and Pelto, M. S.: Mass Balance Measurements on the Lemon Creek Glacier, Juneau Icefield, Alaska 1953-1998, Geogr. Ann. A, 81, 671-681, available at: http://www.jstor.org/ stable/521505, 1999.

Paterson, W. S. B.: The Physics of Glaciers, Pergamon Press, Elsevier, Oxford, UK, 1994.

Patzelt, G.: The Austrian glacier inventory: status and first results, IAHS-AISH P., 26, 181-184, 1978.

Pelto, M. and Riedel, J.: Spatial and temporal variations in annual balance of North Cascade glaciers, Washington 1984-2000, Нydrol. Process., 15, 3461-3472, 2001.

Rabus, B., Harrison, W., and Echelmeyer, K.: Comments on "The use of planimetric surface area in glacier mass-balance calculations: a potential source of errors" by Jacobsen and Theakstone, J. Glaciol., 42, p. 588, 1996.

Reinwarth, O. and Escher-Vetter, H.: Mass Balance of Vernagtferner, Austria, From 1964/65 to 1996/97: Results for Three Sections and the Entire Glacier, Geogr. Ann. A, 81A, 743-751, doi:10.1111/j.0435-3676.1999.00102.x, 1999.

Rolstad, C., Haug, T., and Denby, B.: Spatially integrated geodetic glacier mass balance and its uncertainty based on geostatistical analysis: application to the western Svartisen ice cap, Norway, J. Glaciol., 55(15), 666-680, available at: http://www.ingentaconnect.com/content/igsoc/jog/2009/ 00000055/00000192/art00009, 2009.
Slupetzky, H.: Programm "Wasser- und Eishaushaltsmessungen im Stubachtal" (Massenbilanzmessreihe vom Stubacher Sonnblickkees), Ergebnisbericht für 1992, Mitteilungsblatt des Hydrographischen Dienstes in Österreich, 70, 115-131, 1999.

Soruco, A., Vincent, C., Francou, B., Ribstein, P., Berger, T., Sicart, J., Wagnon, P., Arnaud, Y., Favier, V., and Lejeune, Y.: Mass balance of Glaciar Zongo, Bolivia, between 1956 and 2006, using glaciological, hydrological and geodetic methods, Ann. Glaciol., 50(50), 1-8, 2009.

Thibert, E. and Vincent, C.: Best possible estimation of mass balance combining glaciological and geodetic methods, Ann. Glaciol., 50(7), 112-118, doi:10.3189/172756409787769546, 2009.

Wiesenegger, H. and Slupetzky, H.: Der "Untere Eisboden See" - Entstehung eines neuen Gletschersees beim Stubacher Sonnblickkees, Mitteilungsblatt des Hydrographischen Dienstes in Österreich, 86, 49-63, 2009.

Würländer, R. and Eder, K.: Leistungsfähigkeit aktueller photogrammetrischer Auswertemethoden zum Aufbau eines digitalen Gletscherkatasters, Zeitschrift für Gletscherkunde und Glazialgeologie, 35, 167-185, 1998.

Zemp, M., Jansson, P., Holmlund, P., Gärtner-Roer, I., Koblet, T., Thee, P., and Haeberli, W.: Reanalysis of multi-temporal aerial images of Storglaciren, Sweden (1959-99) - Part 2: Comparison of glaciological and volumetric mass balances, The Cryosphere, 4, 345-357, doi:10.5194/tc-4-345-2010, 2010. 